\title{
Adult age differences in vocabulary acquisition as a function of individual differences in working memory and prior knowledge
}

Lisa L. Laumann

West Virginia University

Follow this and additional works at: https://researchrepository.wvu.edu/etd

\section{Recommended Citation}

Laumann, Lisa L., "Adult age differences in vocabulary acquisition as a function of individual differences in working memory and prior knowledge" (1999). Graduate Theses, Dissertations, and Problem Reports. 3155.

https://researchrepository.wvu.edu/etd/3155

This Dissertation is protected by copyright and/or related rights. It has been brought to you by the The Research Repository @ WVU with permission from the rights-holder(s). You are free to use this Dissertation in any way that is permitted by the copyright and related rights legislation that applies to your use. For other uses you must obtain permission from the rights-holder(s) directly, unless additional rights are indicated by a Creative Commons license in the record and/ or on the work itself. This Dissertation has been accepted for inclusion in WVU Graduate Theses, Dissertations, and Problem Reports collection by an authorized administrator of The Research Repository @ WVU.

For more information, please contact researchrepository@mail.wvu.edu. 


\title{
ADULT AGE DIFFERENCES IN VOCABULARY ACQUISITION AS A FUNCTION OF INDIVIDUAL DIFFERENCES IN WORKING MEMORY AND PRIOR KNOWLEDGE
}

\author{
Lisa L. Laumann \\ Dissertation \\ Submitted to \\ The Eberly College of Arts and Sciences at \\ West Virginia University \\ in partial fulfillment of the requirements \\ for the degree of \\ Doctor of Philosophy \\ in \\ Life-span Developmental Psychology \\ Stanley Cohen, Chair \\ Barry Edelstein \\ Anne Nardi \\ Hayne Reese \\ Constance Toffle \\ 1999 \\ Morgantown, West Virginia
}

Keywords: Cognitive Aging, Learning, Vocabulary, Working Memory 


\title{
ADULT AGE DIFFERENCES IN VOCABULARY ACQUISITION AS A FUNCTION OF INDIVIDUAL DIFFERENCES IN WORKING MEMORY AND PRIOR KNOWLEDGE
}

\author{
Lisa L. Laumann
}

\begin{abstract}
(ABSTRACT)
Older adults often complain of cognitive difficulties, such as the inability to learn new information or recall previously learned information. Previous research shows that many older adults do have difficulties with certain learning tasks. However, not all older adults experience these difficulties. Some recent research has shown that, contrary to popular belief, older adults can learn new information under certain task conditions. The purpose of this investigation was to examine how older adults, compared against younger adults, learn new vocabulary under two different learning task conditions. Each participant engaged in two vocabulary learning tasks: a paired-associate task and a contextual task. Previous research has shown that both working memory and existing vocabulary knowledge are used when learning unfamiliar words. Participants also were given two measures of each individual difference factor (working memory and vocabulary knowledge), as well as an inductive reasoning measure. In confirmation of hypotheses, younger adults had higher scores on the working memory measures and the inductive reasoning task. To the contrary, older adults had higher scores on the measures of existing vocabulary knowledge. Older and younger adults did not significantly differ on scores assigned to definitions given in the contextual task. However, younger adults outperformed older adults in the paired-associate task. In addition, the measures of existing vocabulary knowledge accounted for more variance in the contextual task. Conversely, the working memory measures and the inductive reasoning task accounted for more variance in the paired-associate task. These conclusions are encouraging to those working with older adults. It appears that under certain conditions that focus on older adults' strengths, new information can be learned and cognitive deficits can be overcome.
\end{abstract}




\section{DEDICATION}

I wish to dedicate this dissertation to my grandparents: Wilfred and Cecelia Laumann, and Robert and Roberta Towner. These are the people who originally inspired my interest in older adults. They are all wonderful examples of successful aging. In particular, I wish to recognize my Grampy Towner. He did not always understand why I chose to remain in school so long or what exactly I was studying, but his constant, quiet support was the backdrop upon which I could always lean. Grampy, I am sorry that you cannot join in the celebration of my completion, but I know that your pride is shining down on me. I will have a burger and a beer in your honor! 


\section{ACKNOWLEDGMENTS}

When attempting a project this large in scale there are always many people to thank; those who lead and mentor, those who support and encourage, and those whose influences have brought me to this place and made me who I am today. First, I would like to thank Stan Cohen for stepping in and assisting me with the dissertation process. Without Stan's guidance, advice, and motivation, I never would have been able to complete this process. It is difficult to express the magnitude of my appreciation to him. Along with Stan, I wish to extend my thanks to my committee members whose advice was invaluable in the shaping and completion of this project; Drs. Barry Edelstein, Anne Nardi, Hayne Reese, and Connie Toffle. Connie deserves special recognition because she is not only my committee member, but also a friend who helped me to conceptualize my research ideas.

Other friends have been invaluable to me during my graduate school career. These are friends with whom I was able to "talk shop," laugh, cry, and party. I wish to personally thank Robin Bartlett, Dave Buck, Nicole Guajardo, Charisse Nixon, Cheryl Rode, and Christine Ross for all of their support and encouragement. I would also like to recognize Mary Louk for her involvement in this project and endless hours of data collection.

My family also deserves special thanks. My dad and stepmother have always been ready with an encouraging word and, because of their experiences in graduate school, they have been extremely empathetic. My mom and stepfather have also contributed greatly with their patience and support. I can attribute my perseverance to their example. Finally, I would never have been able to complete this process without my future husband, Michael, standing behind me with assurance and placing confidence in me. 


\section{TABLE OF CONTENTS}

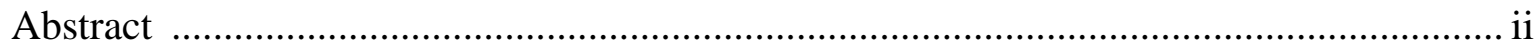

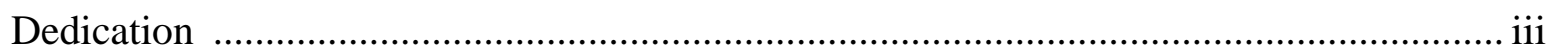

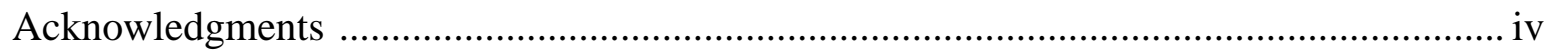

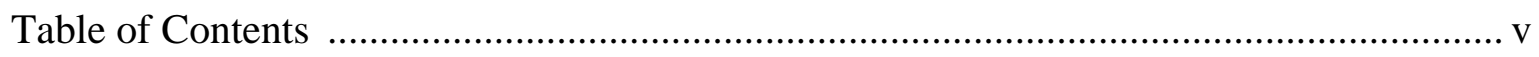

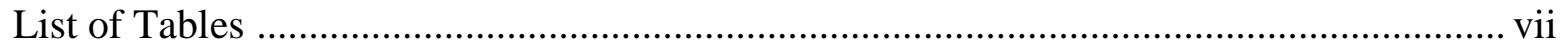

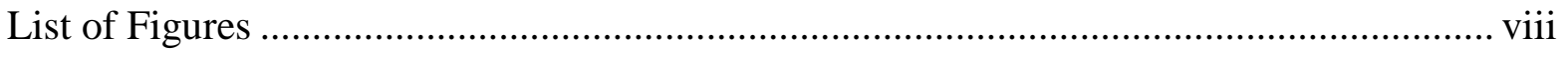

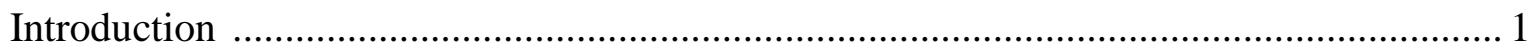

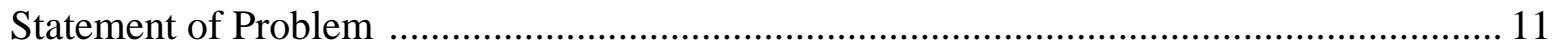

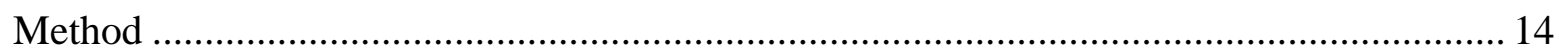

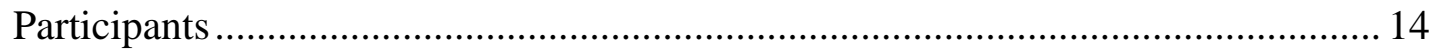

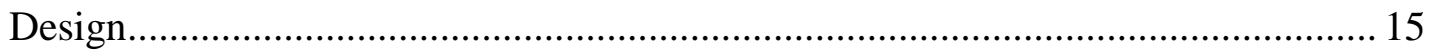

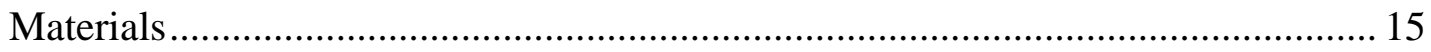

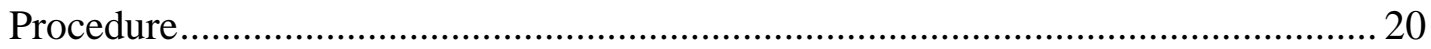

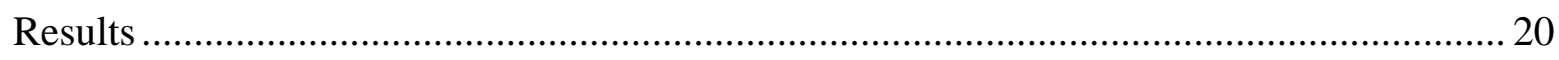

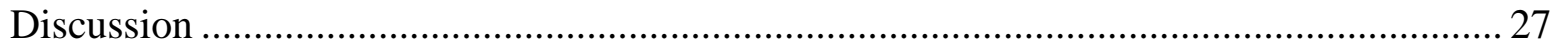

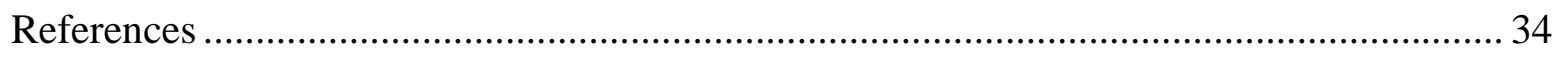

Appendixes

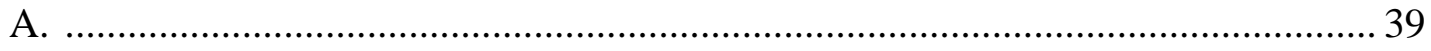

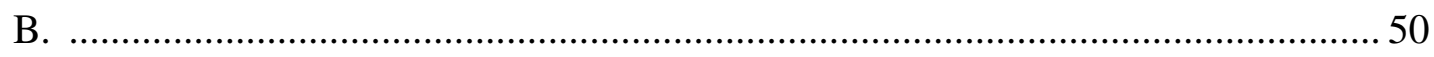

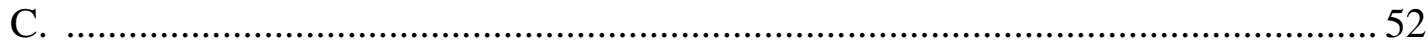

D.

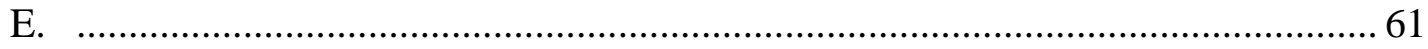




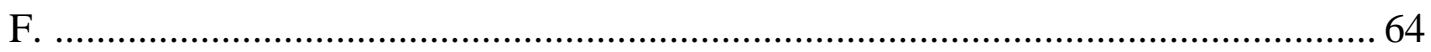

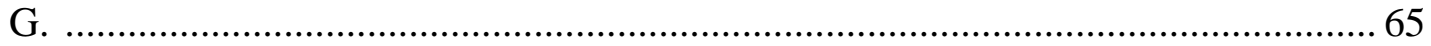

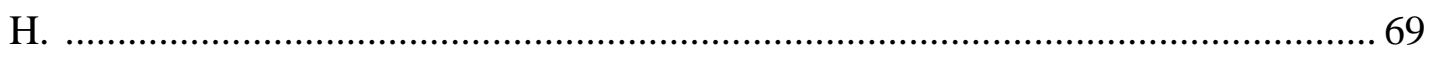

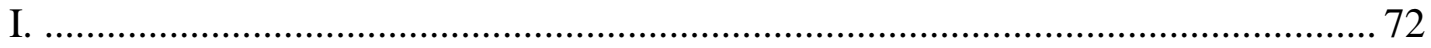

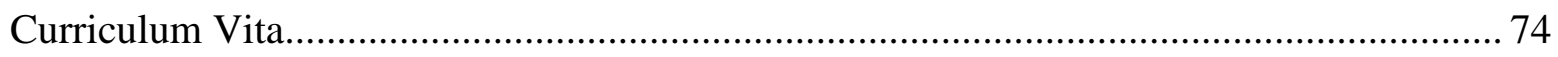




\section{LIST OF TABLES}

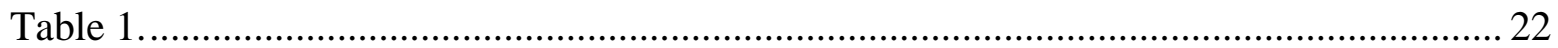

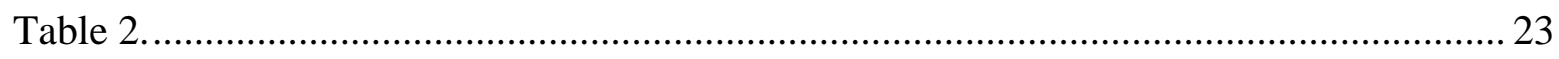

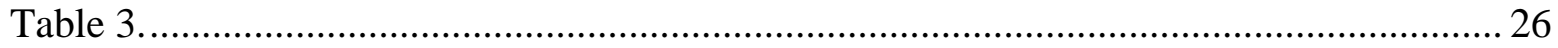

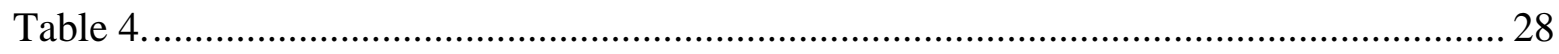

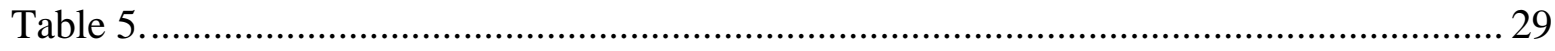




\section{LIST OF FIGURES}

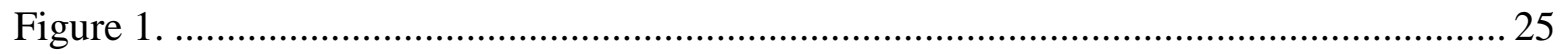


Older adults often complain of cognitive declines, such as the inability to learn new names or remember previously learned names. Indeed, research shows that many older adults have difficulties with certain learning tasks and exhibit lower learning scores compared to younger adults (e.g., Arenberg \& Robertson-Tchabo, 1977; Hultsch \& Dixon, 1990; Kausler, 1991; Service \& Craik, 1993). Presumably, aging leads to memory deficits that can impair our learning processes due to deficiencies in working memory and speed of processing (Salthouse, 1991). However, not all older adults experience these difficulties. Recent research by Laumann (1996) has shown that, contrary to popular belief, older adults can learn new information and, under some task conditions, may show even more learning than younger adults. The term "learning" here is used in a broader sense than in the monistic behavioral sense of simple association. Learning implies the acquisition of knowledge and skills that can later be used for adaptation to changing environments. Learning is usually inferred from a change in performance on a laboratory task after a study, or acquisition, period.

Employing this broader definition of learning still does not clear up the difficulty scholars have had distinguishing between the concepts of learning and memory, perhaps because the two are so obviously related. This distinction has become so blurred that even a recent Handbook of the Psychology of Aging chapter entitled "Learning and Memory in Aging" failed to clearly define and distinguish the differences in these concepts (Hultsch \& Dixon, 1990). Typically, learning suggests improvements on a task due to progressive practice, whereas repeated practice is not necessary for the formation of a memory (Kausler, 1991). Even this distinction becomes unclear, however, when considering certain laboratory tasks. For example, if a participant is asked to learn (or remember) a short list of six words presented once, and later recalls four of the six words correctly, is this a demonstration of learning or memory? If the list is then presented 
again for another study trial and the participant correctly recalls all six words, is this learning or memory?

Craik (1977) framed the distinction within changing theoretical perspectives and the different tasks typically employed by those perspectives. According to this framework, learning is the formation of new associations between stimulus and response elements presented several times and is usually studied from an associationist perspective. With a shift to studying human cognition from an information processing perspective, a shift also appeared in the focus and method of study. The focus of study from this perspective is the factors which affect the participant's memory for materials presented in a single study trial. Even with this further clarification, the distinction remains uncertain (Kausler, 1991). In order to incorporate the broader definition of learning (acquisition of knowledge and skills that can later be used), the present study investigated age differences apparent in both associationist studies and information processing studies.

The broad purpose of the present research was to examine the learning process at different points in the adult life span and across different task conditions. This approach should help us to better understand how adults of different ages learn. In addition, further exploration into the conditions under which adults of different ages successfully acquire new information is needed. Kausler felt that it is "essential that we discover the extent to which learning proficiency is affected by human aging and that we understand the reasons why it is so affected" (1991, p. 190). The information gained about variables that influence and enhance learning could be used to design materials and interventions to facilitate learning in different age groups. For example, some conditions that have been shown to enhance learning performance for older adults are 
distinct organization of materials and specific instruction on cognitive strategies (Cavanaugh, 1997; Kausler, 1991).

To address this broad research goal, two studies which investigated vocabulary learning in adults were examined: Service and Craik (1993) and Laumann (1996). Service and Craik found that older adults did not learn as many vocabulary words as younger adults in a pairedassociation task. Laumann (1996), using a unique semantic contextual task, found that older adults were better at learning the meaning of words than younger adults. Literature on the following topics was reviewed first in order to understand the specifics of the two contradicting studies: age differences in paired-associate vocabulary learning, in working memory, in acquiring vocabulary from semantic context, and in prior knowledge base. In addition, the "selective optimization with compensation" model of cognitive aging was employed as a theoretical explanation of the contradictory age differences in vocabulary acquisition given differing task conditions (Baltes, 1993).

Age differences in paired-associate vocabulary learning

Paired-associate tasks have been the prototypical task utilized in verbal-learning research. In this type of task, lists of word pairs are presented in a stimulus and response format. The participants' assignment is to learn to respond with the correct response, when its stimulus is presented alone (cued-recall). At first glance, this type of task may not seem ecologically valid outside of a formal school environment. However, there are many real-life instances in which one is required to make and remember an association, for example identifying a name with a face or a sports team with a city or region. Because this type of learning does occur throughout the lifespan, it is important to investigate age differences in this area (Kausler, 1991). Older adults 
commonly display deficits in learning in studies employing paired-associate tasks (Arenberg \& Robertson-Tchabo, 1977; Kausler, 1991; Salthouse, 1982; Salthouse, Kausler, \& Saults, 1988).

Early studies on age differences in paired-associate learning often failed to take attributes other than age into consideration. The conclusion that older adults were deficient in pairedassociate performance had to be qualified by taking education level and verbal ability into consideration. In an attempt to disentangle cohort effects from age differences, Salthouse et al. (1988) used large samples of younger adults who were not in college, as well as college student younger adults, as comparisons to middle-aged and older adults' performance on a pairedassociate task . In this task, participants were given two trials to study lists of eight pairs of nouns. The experience of being in college was an advantage to learning, as this group of young adults had the highest percentage of correct responses. However, even when compared to noncollege young adults, middle-aged and older adults exhibited deficits in learning. That is, their percentages of correct responses after the second study trial were significantly lower than the percentages of college and noncollege younger adults. Therefore, age-related variables other than education level contributed to age differences.

Service and Craik (1993) used a traditional paired-associate task to assess learning of new words in younger and older adults. Participants in the Service and Craik study were told to learn lists of eight word pairs consisting of a familiar English word and an unknown foreign (meaningless, novel) word. Participants were told that word pairs were not synonyms. After the lists were presented, the participants were asked to recall the correct foreign word (response), when cued with its paired English word (stimulus). Participants were given four learning trials with the list. Results indicated a main effect of age, with younger participants learning more 
word-pairs. In this study learning was measured by mean number of correct responses given on the fourth trial.

One explanation for the age differences found in paired-associate tasks has focused on the effort required by these tasks to form some association between the stimulus-response and retain that association to an essentially meaningless word for later recall.

\section{Age differences in working memory}

In a paired-associate task, participants need to keep stimulus-response pairs organized, remember which response belongs to which stimulus, and then use a strategy to remember the relationships. Because of this effort involved, paired-associate tasks rely heavily on working memory (Service \& Craik, 1993). Working memory is generally defined as a construct that contains both processing and storage components (Baddeley, 1981). "The concept of working memory refers to the processes and structures involved in simultaneously holding information in mind and using that information (often in combination with further incoming information) to solve a problem, make a decision, or learn some new concept" (Craik \& Jennings, 1992, p. 56). Presumably, learning new vocabulary under paired-associate conditions actively utilizes working memory because it requires that information about a stimulus be stored as an association is made to its correct response. To the extent that working memory is critical to learning new associations, it would be expected that older adults would have difficulties learning under pairedassociate conditions because they typically exhibit deficits on working memory tasks (see, e.g., Craik \& Jennings, 1992).

A number of researchers have identified age differences in the functioning of working memory (e.g., Craik, Morris, \& Gick, 1990; Dobbs \& Rule, 1989; Salthouse, Babcock, \& Shaw, 1991; Wingfield, Stine, Lahar, \& Aberdeen, 1988). Tasks that test the functioning of working 
memory are more complex than passive repetition span tasks. Craik and Rabinowitz (1984) proposed that short-term memory tasks lie on a continuum from those tapping primary memory, which involve passive holding and repetition of a small amount of information, to those tapping working memory, which are complex tasks involving simultaneous storage and further processing. Therefore, working memory tasks must "demand simultaneous storage of recently presented material and processing of additional information" for later recollection or use (Hultsch \& Dixon, 1990, p. 261). Wingfield et al. (1988) employed a variety of tasks that increased in complexity to examine which aspects of short-term memory were most affected by age. These researchers gave groups of older adults and younger adults three memory tasks: a digit span task, thought to be a more pure measure of primary memory; a word span task, which increases in difficulty because the stimuli are now verbal; and a sentence span task, similar to reading span (Daneman \& Carpenter, 1980) and thought to tap working memory because participants must hold the last word of each sentence in mind for later recall (storage component) while reading the next sentences aloud (processing component). They found no age differences in digit span, slight age differences in word span, and significant age differences in the reading span task. Their results confirmed the hypothesis that age effects are more obvious as tasks become more complex, that is, as they move along the continuum from primary memory to working memory.

Extensive research has been completed looking at age differences in working memory. Most of this research has supported the interpretation that age differences become present and/or increase with task complexity (Craik et al., 1990; Dobbs \& Rule, 1989; Gick, Craik, \& Morris, 1988; Laumann, 1996; Salthouse, Babcock, \& Shaw, 1991; Wingfield et al., 1988). Although the details of exactly which components (processing or storage) of working memory are affected by 
age are somewhat controversial (e.g., compare Salthouse et al., 1991, with Craik et al., 1990), cognitive aging researchers generally agree that there are large and reliable age-related declines in performance on tasks designed to require active use and manipulation of information (Salthouse, 1991; Salthouse \& Babcock, 1991).

Given that working memory deficits may create a disadvantage for older adults trying to learn new vocabulary in paired-associate task conditions, the results of Service and Craik (1993) are not surprising.

\section{$\underline{\text { Age differences in learning vocabulary from context }}$}

Intuitively, we might expect that knowledge is not always acquired in a paired-associate manner, but rather embedded within some context. For example, learning that the professional football team, the Steelers, play in Pittsburgh, Pennsylvania may be more than a mere pairedassociation task. For some it may contain contextual information. For instance, for those who know the history of Pittsburgh as a big iron mining and steel producing city, this information would place the Steelers - Pittsburgh pair within a context, and therefore be easier to learn and remember. Many researchers have examined this idea that "knowledge is situated, being in part a product of the activity, context, and culture in which it is developed and used" (Brown, Collins, \& Duguid, 1989, p. 32). These researchers propose that many laboratory studies of vocabulary, and the education system in general, have focused too much on rote memorization of word meanings, rather than the entire learning process which must include the context.

Previous research on children, young adults, and older adults has shown that much vocabulary learning does take place, not in a paired-associate manner, but rather, within a context (Daneman \& Green, 1986; Laumann, 1996; Miller \& Gildea, 1987; Sternberg, 1987; Sternberg \& Powell, 1983). That is, many word meanings are inferred from cues in the 
surrounding prose text or conversation in which the novel word is encountered. An individual's lexicon is so large that it is highly unlikely that a person intentionally studied the meanings of all the words that he or she knows. We have all had the experience of coming across an unfamiliar word in the context of reading or conversation. To understand a novel word, we piece together a meaning for it from the surrounding information. By picking out details from the context that we think are relevant, we construct a meaning of the unfamiliar word. The meaning of the novel word has thus been inferred from the context in which it occurred.

In a recent study (Laumann, 1996), older adults and college students gave definitions for rare, novel words that appeared in short passages containing context cues (see Appendix A for examples). They were instructed to use any relevant information from the reading passage in constructing their definitions. Contrary to original predictions, older adults received higher scores on the definition task than the college students, even with education level controlled. Perhaps, under these conditions, older adults were better at learning vocabulary from context than younger adults. This finding may have been a result of the specific conditions of this vocabulary task. In learning situations that more closely mimic everyday experiences of older adults, their accumulated knowledge and experiences help them to learn better than less experienced younger participants (Hess \& Pullen, 1996).

\section{$\underline{\text { Age differences in prior vocabulary knowledge }}$}

One reason older adults give better definitions may be their strong accumulated knowledge of word meanings. Researchers have proposed that we use what knowledge we already have in order to learn and incorporate new information. The literature indicates that an individual's knowledge base increases throughout the life span (Kausler, 1991). We know that, with age, people have had more opportunities to increase their vocabulary. They have increased 
exposure to new words because they have more experiences, both work-related and pleasurable, reading more and having more conversations (Salthouse, 1988). Numerous studies have demonstrated that older adults have a strong knowledge base in vocabulary (e.g., Kaufman, 1990; Kaufman, Reynolds, \& McLean, 1989; Kausler \& Puckett, 1980; Salthouse, 1991; Salthouse, 1993; Smith \& Earles, 1996) and show little if any declines in vocabulary until the last decades of life.

Since the organization of one's vocabulary can influence learning, it is important when examining vocabulary acquisition to determine whether age differences in lexical organization exist. The way knowledge of word meanings is organized may affect how it can be used in acquiring new, related knowledge, such as in learning new vocabulary. After a thorough review of the relevant literature, Light (1991) concluded that "neither the organization of concepts nor the characteristics of semantic activation varies with age" (p. 342). Younger and older adults encode and organize information similarly, although older adults may be slightly slower to access that information (Bowles, 1994). Thus, there is no reason to hypothesize that age would lead to difficulties in learning new words as a function of existing knowledge. The organization of this existing vocabulary knowledge may help in learning new vocabulary.

Thus, the resource of a large, organized vocabulary base may be an advantage for older adults in learning new vocabulary (Laumann, 1996). This is in contrast to the evidence of agerelated decrements from research on paired-associate tasks and working memory deficits that may be a disadvantage for older adults.

\section{$\underline{\text { Selective Optimization with Compensation }}$}

Baltes' (1993) "selective optimization with compensation" model of cognitive aging may help to explain the discrepant findings of Service and Craik (1993) and Laumann (1996). In his 
model, Baltes uses a customary "dual-process categorization" of intelligence to help explain differences in learning that may occur across the adult life span (1993, p. 581). His model makes a distinction between the "mechanics" of cognition and the "pragmatics" of cognition. Using more familiar terminology, the mechanics of cognition are similar to fluid intelligence, which include flexible, innate reasoning abilities dependent on the neurophysiology of the brain (Baltes, 1993). Mechanics can be operationalized by measuring the speed and accuracy of basic processes. Because mechanics are contingent on biology, the developmental trajectory indicating losses in mechanics with age is not surprising.

On the other hand, the pragmatics of cognition are more similar to crystallized intelligence, and include such items as facts and skills acquired over time, and are often measured using vocabulary tests. This type of intelligence is thought to reflect the impact of one's experience within an education system and culture. Therefore, pragmatics can be expected to increase through the life-span. Indeed, the ideal life-span trajectory of pragmatics displays "evidence for stability and positive change in persons who reach old age without specific brain pathology" (Baltes, 1993, p. 580).

Baltes' theory goes beyond conventional classifications of intelligence with the addition of the concept of compensation. His theory is that older adults, who must deal with varying degrees of loss in functioning, use strengths in other areas to offset these losses, or compensate for them. According to the dual-process categorization of cognition, older adults, who inevitably face declines in the abilities relevant to the mechanics of cognition, compensate by emphasizing their strong pragmatics of cognition, thereby optimizing their performance. In relation to learning, the processes involved may change, or shift in importance, over the adult life span. That is, adults of different ages may learn differently, according to their unique strengths and 
weaknesses. According to this model, younger adults would be expected to rely on strong mechanics in learning, and thereby do very well on a paired-associate task. Conversely, older adults would rely on strong pragmatics, and do better on a learning task that emphasizes their experience.

This brief literature review highlighted the fact that much previous research has used traditional verbal-learning techniques, such as paired-associate tasks, to assess age differences in verbal learning (Service \& Craik, 1993). One study that used a different approach to measure learning found age differences favoring older adults, contrary to previous research (Laumann, 1996). Two abilities relevant to learning vocabulary are working memory and vocabulary knowledge (Daneman \& Green, 1986). The research on these two abilities has demonstrated age discrepancies, in that younger adults are better at working memory tasks, while older adults have a stronger existing vocabulary. It is not apparent exactly which aspects of these two abilities or aspects of differing task conditions are contributing to age differences in research examining knowledge acquisition. Further research in these areas is needed to understand age differences in learning.

\section{Statement of Problem}

The purpose of this research was to examine how older adults, compared with younger adults, can learn new information, regardless of anecdotally reported learning difficulties. Vocabulary tasks can be employed as a way to assess this learning. In a paired-associate vocabulary learning task, older adults did not learn as many word pairs as younger adults (Service \& Craik, 1993). This type of task emphasizes the mechanics of cognition (working memory). From Baltes' model, one can predict that older adults would not do well on this type of task because they have deficits in this area. However, Laumann (1996) provided evidence that 
older adults can learn new vocabulary, given a contextually rich learning task. A more ecologically valid vocabulary task (in context) emphasizes the pragmatics of cognition. In terms of Baltes' model, older adults faced with deficits in the abilities relevant to the mechanics of cognition (working memory) compensate by emphasizing the pragmatics. By this theory, older adults can be expected to rely heavily on their existing vocabulary knowledge to acquire new vocabulary.

The present study expanded on previous research by providing a within-subject comparison of different learning conditions. This study directly compared vocabulary learning in a vocabulary-in-context task and a paired-associate task among adults of different age groups. This should lead to better understand how adults of different ages learn and how we can emphasize strengths to facilitate learning. This study also attempted to confirm previously reported findings of Laumann (1996), as well as investigate the implications of Baltes' model. In support of predictions following from Baltes' model, existing vocabulary knowledge (pragmatics) contributed more to extracting word meaning from context than did working memory (mechanics) for the older adults (Laumann, 1996). Apparently, older adults were selectively optimizing their performance by compensating for reduced mechanics using pragmatics. However, Laumann's (1996) hypotheses concerning younger adults' reliance on mechanics were not supported. Other researchers (Daneman \& Green, 1986) have shown that working memory capacity was strongly related to novel word definition production among college students. Laumann (1996) did not find that younger or older participants relied on mechanics (working memory) to define novel words. Thus, further research into the relations among age, learning conditions, vocabulary acquisition, and related intellectual abilities was needed. 


\section{$\underline{\text { Research hypotheses }}$}

Based on Baltes' model and the findings of Service and Craik (1993) and Laumann (1996), the following predictions were made:

1. Older adults display higher scores on tests of pragmatics of cognition than younger adults. Two standard vocabulary tests, a recall and a forced recognition task, were used to assess pragmatics. It was hypothesized that older adults' scores on these tests would be higher than younger adults' scores.

2. Younger adults display higher scores on tests of mechanics of cognition than older adults; mechanics was operationalized using working memory span tasks with verbal stimuli. Younger adults were expected to out-perform older adults on these span tasks.

3. Older adults do better on a learning task that allows their rich vocabulary knowledge base (pragmatics) to assist in the learning than on a task that emphasizes mechanics. Consistent with Laumann (1996) older adults have higher vocabulary-in-context learning scores than younger adults.

4. Younger adults do better on a learning task that emphasizes cognitive mechanics over pragmatics. That is, younger adults do better on the paired-associate learning task than the older adults.

5. In addition, older participants' learning performance is enhanced more than younger adults' performance by a task that allow them to take advantage of their experiences. When comparing the learning between the two age groups, older adults exhibit a greater increase in learning scores in the vocabulary-in-context task than young adults.

6. The paired-associate learning task scores are more related to the mechanics of cognition than the pragmatics. That is, the scores of the paired-associate learning task are more highly 
correlated with working memory span scores than with vocabulary test scores. In addition, the working memory predictor tasks account for more variance in the paired-associate task than the vocabulary-in-context task.

7. Conversely, the vocabulary-in-context learning task scores are more related to the pragmatics of cognition than the mechanics. The vocabulary-in-context learning task have higher correlations with the vocabulary test scores than the working memory span scores. The vocabulary knowledge predictors also account for more variance in the pragmatics based learning task, the vocabulary-in-context task.

\section{Method}

\section{$\underline{\text { Participants }}$}

A total of 64 individuals participated, 32 older adults and 32 younger adults, with 16 males and 16 females in each age group. The younger adults, ranging in age from 18 to $26, \underline{\mathrm{M}}=$ 21.41, $\underline{\mathrm{SD}}=2.21)$ were recruited from undergraduate psychology classes at West Virginia University. They received course credit for their participation in this study. The older adults, with ages ranging from 61 to $90, \underline{\mathrm{M}}=72.54, \underline{\mathrm{SD}}=7.47)$ were healthy, community-dwelling individuals from the Morgantown, West Virginia area. They were paid $\$ 10.00$ for their participation. The older and younger adults did not significantly differ in their self-perceived health on a five-point scale $(1=$ excellent and $5=$ poor $), \underline{\mathrm{M}}=2.09(\underline{\mathrm{SD}}=0.96)$, and $\underline{\mathrm{M}}=1.94(\underline{\mathrm{SD}}$ $=1.01)$, respectively, $\underline{\mathrm{t}}(62)=0.63, \underline{\mathrm{p}}>.05$. The age groups also did not significantly differ in years of education, $\underline{t}(62)=1.44, \underline{p}>.05$, in partial control for typical cohort effects in cognitive studies. The older adults had an average of 15.16 years $(\underline{\mathrm{SD}}=3.16)$ of formal education, whereas the younger adults had an average of 14.28 years $(\underline{\mathrm{SD}}=1.33)$. 


\section{$\underline{\text { Design }}$}

Each participant engaged in two learning tasks. The variables comprised a 2 (age: old, young) x 2 (gender) x 2 (order: task given first) x 2 (learning task: paired-associate, vocabularyin-context) mixed model design, with age, gender, and order of learning task as between-subject variables and learning task as the within-subject variable. Determination of which learning task was administered first to each participant was counterbalanced across age (Reese, 1997), but not gender.

\section{$\underline{\text { Materials }}$}

Demographic questionnaire. This basic questionnaire was designed to measure demographic characteristics of the participant, such as age, gender, years of formal education, self-perceived health compared to others in same age group, listing of medications a participant is taking, as well as the last time those medications were taken. (See Appendix B for questionnaire.)

Each participant completed two vocabulary learning tasks -- a paired-associate vocabulary task and a vocabulary-in-context task. The order of these two tasks was counterbalanced.

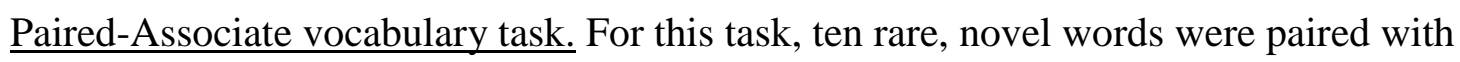
similar length infrequent, but familiar, recognizable words. The novel words were taken from Daneman and Green's (1986) study and were calibrated in difficulty to the novel words used in the Vocabulary-in-Context task (see below). These pairs were used in a five-trial pairedassociate task. Each trial used the same pairs presented in mixed random orders (see Appendix C for pairs and orders). During the study time, the experimenter presented the word pair visually, read each one aloud, and requested that the participant do the same, resulting in an approximate 
two second exposure to each pair during each trial. Following the study time, participants were presented with the rare, novel word pair member (stimulus) and asked to supply the common word match (response). The number of correct responses out of ten on the fourth trial was used as the raw learning score on this task because pilot studies indicated that this would not result in floor or ceiling effects. These learning scores were transformed to have a mean of zero and a standard deviation of one in the combined groups in order to compare performance across the two different learning tasks.

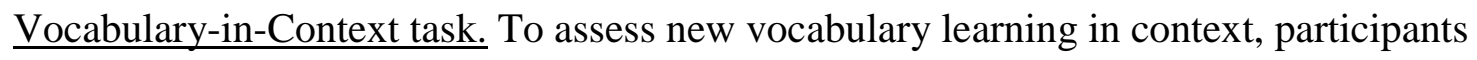
read 10 passages, taken from 24 originally developed by Daneman and Green (1986). Each passage contained a real, but uncommon word not in current usage. To ensure the novelty of the target word, participants were asked if they could identify the word before beginning each passage. No participant was familiar with any of the ten target words. Daneman and Green designed these passages to be one page stories that described a scenario and contained numerous cues as to the meaning of the novel word. (See Appendix A for passages.) The instructions were to try to piece together the meaning of the target word based on details supplied throughout the story passage. Participants were asked to read each passage aloud to the experimenter to ensure task adherence.

Immediately after reading each passage, participants were asked to supply as precise a definition of the target word as possible. Two raters independently scored the definition responses for each of the ten words on a 0,1 , or 2 point system, based on the scoring system developed by Laumann (1996). A score of 0 was given to definitions that were completely incorrect, a score of 1 for a definition that incorporated at least one element of the meaning, and a score of 2 for a definition that incorporated all elements of the actual word meaning (see 
Appendix D for scoring manual). Cohen's kappas were computed for each word to measure the scoring agreement between the raters. These values ranged from 0.75 to $0.92, \underline{M}=0.86$. Total scores were transformed to have a mean of zero and a standard deviation of one in the combined group to compare learning on this task and the paired-associate task..

Participants completed two tasks to assess working memory capacity: alphabetic span and reading span (Daneman \& Carpenter, 1980). Generally, span tests start with an easy load of information (i.e., only a few things to remember) which the participant must repeat. The load is systematically increased until the participant is no longer able to repeat the information in the required order. Age differences have been found using both of the selected working memory span tasks (e.g., Craik, 1986; Craik et al., 1990; Laumann, 1996; Light \& Anderson, 1985; Wingfield et al., 1988).

Alphabetic span test. An alphabetic span test was administered. For this task, the participant was asked to recall each list of presented nouns in alphabetic order. For example, given the words "brick," "apple," and "candy," the correct response would be "apple, brick, candy." This word span task used 66 two-syllable nouns, four to six letters in length, with high concreteness ratings (Friendly, Franklin, Hoffman, \& Rubin, 1982) (see Appendix E for list of nouns used in this task). These nouns were then divided into non-alphabetized lists and given to each participant in the same randomized order. The experimenter started by reading three nouns to the participant and asked the participant to repeat the words in alphabetical order. If the participant recalled the three words in correct alphabetic order, a second trial with three different nouns was given. If these were recalled in the correct order, the experimenter then read four different nouns. The number of nouns per set continued to increase (up to eight) as long as the participant was able to recall the words correctly for at least one of the two trials per set. The 
participant's score on this task was the number of words in the last trial with all words correctly recalled.

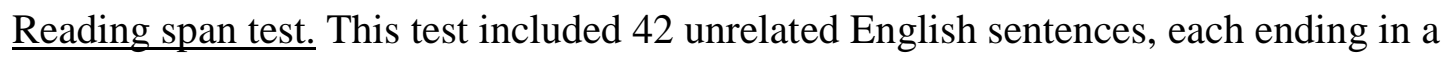
different word. Sentences from Salthouse and Babcock (1991) were used. The sentences were fairly short, between six and ten words in length, and ended with common words found in a child's dictionary. The sentences are included in Appendix F. Each sentence was typed on a card and the cards were arranged to include three trials each of two, three, four, and five sentence sets. Blank cards were inserted at the beginning of each new set. The experimenter presented one card at a time to the participant. The participant read the sentence aloud and then a new sentence was presented. This continued until a blank card, signifying the end of a set, was presented. The participant was then asked to recall the last word of each sentence from the preceding set in serial order. The experimenter continued presenting sets with an increasing number of sentences until all of the two-sentence sets were presented. If a participant correctly recalled the last words of at least one two-sentence trial in serial order, then the three-sentence sets were presented, and so on. A participant was assigned a reading span score between two and five, depending on how many sentences were in the last set from which he or she correctly recalled the last words in serial order.

Two vocabulary tests were administered to measure participants' prior vocabulary knowledge: WAIS-R vocabulary subtest (Wechsler, 1981), and a multiple choice synonym vocabulary test (Gardner \& Monge, 1977). Age differences have been found using each of these tests (Kaufman, Reynolds, \& McLean, 1989; Laumann, 1996; Park \& Shaw, 1992).

WAIS-R vocabulary subtest. The WAIS-R vocabulary subtest was administered according to the guidelines in the testing manual (Wechsler, 1981). This is a recall test of 
vocabulary, for which the participants were asked to supply definitions to 35 words of increasing difficulty. (See Appendix G for instructions and examples and Wechsler (1981) for complete word list). The experimenter recorded the participants' definitions verbatim. The definitions were given a score of 0,1 , or 2 depending on the content of the definition, not the expression (for examples of scoring, see Wechsler, 1981).

The average reliability coefficient reported for the WAIS-R vocabulary test, across ages 16-74, is 0.96, obtained using the split-half technique corrected by the Spearman Brown formula (Wechsler, 1981). In order to determine whether the reliability of this test varies with age, different age groups have been tested. The reliability coefficients for the age groups used in this study are: for 18- to 19-year olds, 0.96; for 20-to 24-year olds, 0.94; and for 65- to 69-, and 70to 74-year olds, 0.96 and 0.85 respectively. Based on the published reliability coefficients, this test appears to measure vocabulary knowledge consistently across different age groups. Validity of the WAIS-R as an overall measure of general intelligence is respectable. However, information on the validity of the vocabulary subtest is not available.

Synonym vocabulary test. This 30 -item forced-choice recognition vocabulary test required that participants pick a synonym for each given word from five choices. Participants were given one point for each correct choice for a total of 30 possible points (Gardner \& Monge, 1977). Similar to the WAIS-R subtest, the words in the synonym test increased in difficulty. A copy of this test in included in Appendix H.

Letter Sets test. A task measuring inductive reasoning ability, which is involved in forming hypotheses to fit a set of data, was included to indicate possible links between extracting meaning from the vocabulary-in-context passages and inductive reasoning. This test was used as an additional check of the construct validity of the vocabulary-in-context task. Each item in the 
Letter Sets test (Ekstrom, French, Harman, and Derman, 1990) included five sets of four letters each. The participant's task was to find the rule that relates four of the sets to each other and to mark the one that does not fit the rule. This test is timed, allowing 7 minutes for the first 15 items and an additional 7 minutes for the second set of 15 items. (See Appendix I for the instructions for Letter Sets test.) The individual's score on this test was the number of items correct minus $1 / 5$ of the incorrectly answered items to discourage guessing.

\section{$\underline{\text { Procedure }}$}

As the participant entered the laboratory, he or she was greeted by an experimenter and told that the purpose of the study was to examine adult age differences in vocabulary learning. After reading and signing the consent form, the participant and the experimenter together filled out the demographic questionnaire. Each participant was then given the vocabulary-in-context task and the paired-associate vocabulary task. The order of these two tasks was counterbalanced within each age group, but not across gender. The predictor tasks (the two vocabulary knowledge tests, the two working memory tasks, and the inductive reasoning task) followed in that set order to minimize fatigue. One of the older male participants refused to complete the paired-associate task. Three different older male participants and one older female participant did not complete the Letter Sets test. As a consequence, some analyses include slightly different numbers of observations. Time was allotted at the end of testing for answering any questions the participants had about the experiment. The session took approximately one and a half hours.

\section{Results}

Descriptive information on the participants, including mean task performance and standard deviations, by age and gender, on the two learning tasks and the five predictor measures thought to be related to vocabulary learning are presented in Table 1. t-test values, and 
significance levels, comparing the means of the two age groups on the five predictor tasks are also presented in Table 1, showing that all expected age differences in performance on the predictors were significant. As expected, older adults scored significantly higher on the measures of pragmatics of cognition, but the younger adults scored significantly higher on the measures of mechanics of cognition. As can be seen in the table, older adults performed significantly better than the younger adults on the measures of prior vocabulary knowledge, or pragmatics of cognition, that is, the WAIS-R vocabulary subtest and the synonyms test. However, the older participants did not perform as well as younger adults on the Letter Sets task, or the working memory tasks (alphabetic span and reading span), shown to indicate mechanics of cognition. Interestingly, although the Letter Sets test was originally included to examine relations of inductive reasoning to the vocabulary-in-context task, this measure showed a higher correlation with the paired-associate task (see Table 3).

A mixed factor analysis of variance, with age, gender, and task order as between subject variables, and type of learning task as a within subject variable was conducted to examine performance on the two learning tasks, paired-associate and vocabulary-in-context. The results of the ANOVA are presented in Table 2. Significant main effects of age and gender were evident. However, task order, that is, which learning task was administered first or_second, was not significant in any effect. In addition, the expected interaction between age group and task condition was significant. Individual means were compared with LSD tests using the pooled within-subjects error term from the ANOVA. The means of each age group on the learning tasks are graphed in Figure 1. Contrary to original hypotheses based on Laumann (1996), older and younger adults' performance did not significantly differ on the vocabulary-in-context learning task $(\underline{t}(62)=1.096, \underline{p}>.05)$. However in confirmation of hypotheses, younger adults out- 
Table 1. Means and Standard Deviations on the Learning Tasks and the Predictor Tasks by Age Group and Gender

\begin{tabular}{|c|c|c|c|c|c|c|c|c|}
\hline & \multicolumn{3}{|c|}{ Younger $(\mathrm{N}=32)$} & \multicolumn{3}{|c|}{ Older $(\mathrm{N}=32)$} & & \\
\hline Task & $\begin{array}{c}\text { Male } \\
(\mathrm{N}=16)\end{array}$ & $\begin{array}{l}\text { Female } \\
(\mathrm{N}=16)\end{array}$ & Combined & $\begin{array}{c}\text { Male } \\
(\mathrm{N}=16)\end{array}$ & $\begin{array}{l}\text { Female } \\
(\mathrm{N}=16)\end{array}$ & Combined & $\underline{\mathrm{t}}$ & df \\
\hline PA & $\begin{array}{c}6.63 \\
(2.99)\end{array}$ & $\begin{array}{c}8.37 \\
(1.67)\end{array}$ & $\begin{array}{c}7.50 \\
(2.54)\end{array}$ & $\begin{array}{c}3.47^{\mathrm{a}} \\
(2.88)\end{array}$ & $\begin{array}{c}4.63 \\
(3.50)\end{array}$ & $\begin{array}{c}4.06 \\
(3.21)\end{array}$ & ----- & ---- \\
\hline VIC & $\begin{array}{c}7.81 \\
(3.12)\end{array}$ & $\begin{array}{l}10.13 \\
(3.40)\end{array}$ & $\begin{array}{c}8.97 \\
(3.42)\end{array}$ & $\begin{array}{c}9.56 \\
(2.92)\end{array}$ & $\begin{array}{l}10.00 \\
(3.86)\end{array}$ & $\begin{array}{c}9.78 \\
(3.38)\end{array}$ & ----- & ---- \\
\hline Alpha Span & $\begin{array}{c}4.75 \\
(0.86)\end{array}$ & $\begin{array}{c}4.81 \\
(0.75)\end{array}$ & $\begin{array}{c}4.78 \\
(.079)\end{array}$ & $\begin{array}{c}3.75 \\
(1.06)\end{array}$ & $\begin{array}{c}3.88 \\
(0.62)\end{array}$ & $\begin{array}{c}3.81 \\
(0.86)\end{array}$ & $-4.69^{* *}$ & 62 \\
\hline Reading Span & $\begin{array}{c}4.00 \\
(0.52)\end{array}$ & $\begin{array}{c}4.25 \\
(0.58)\end{array}$ & $\begin{array}{c}4.13 \\
(0.55)\end{array}$ & $\begin{array}{c}3.63 \\
(0.62)\end{array}$ & $\begin{array}{c}3.31 \\
(0.70)\end{array}$ & $\begin{array}{c}3.47 \\
(0.67)\end{array}$ & $-4.27^{* *}$ & 62 \\
\hline WAIS - R & $\begin{array}{l}48.13 \\
(7.14)\end{array}$ & $\begin{array}{l}46.38 \\
(7.76)\end{array}$ & $\begin{array}{l}47.25 \\
(7.39)\end{array}$ & $\begin{array}{l}55.00 \\
(7.72)\end{array}$ & $\begin{array}{c}50.62 \\
(11.56)\end{array}$ & $\begin{array}{l}52.81 \\
(9.92)\end{array}$ & $2.54^{* *}$ & 62 \\
\hline Synonym & $\begin{array}{l}12.31 \\
(3.96)\end{array}$ & $\begin{array}{l}12.13 \\
(3.56)\end{array}$ & $\begin{array}{l}12.22 \\
(3.70)\end{array}$ & $\begin{array}{l}19.75 \\
(6.93)\end{array}$ & $\begin{array}{l}19.44 \\
(6.75)\end{array}$ & $\begin{array}{l}19.59 \\
(6.73)\end{array}$ & $5.43^{* *}$ & 62 \\
\hline Letter Sets & $\begin{array}{l}17.40 \\
(6.06)\end{array}$ & $\begin{array}{l}18.61 \\
(5.39)\end{array}$ & $\begin{array}{l}18.01 \\
(5.68)\end{array}$ & $\begin{array}{l}13.62^{b} \\
(4.17)\end{array}$ & $\begin{array}{l}11.65^{\mathrm{a}} \\
(5.56)\end{array}$ & $\begin{array}{l}12.56 \\
(4.97)\end{array}$ & $-3.92^{* *}$ & 58 \\
\hline $\begin{array}{l}* * \mathrm{p}<.01 \\
\text { a } \mathrm{N}=15 \\
\mathrm{~b} N=13\end{array}$ & & & & & & & & \\
\hline
\end{tabular}


Table 2. Analysis of Variance Table of Factors Related to Performance on Learning Tasks

\begin{tabular}{|c|c|c|c|c|c|}
\hline Between-Subjects Effects & SS & df & MS & $\mathrm{F}$ & $\begin{array}{c}\text { Partial } \\
\text { Eta }^{2}\end{array}$ \\
\hline Age Group & 4.687 & 1 & 4.687 & $4.705^{*}$ & 0.079 \\
\hline Gender & 6.361 & 1 & 6.361 & $6.385^{*}$ & 0.104 \\
\hline Order & 0.277 & 1 & 0.277 & 0.278 & 0.005 \\
\hline Age Group X Gender & 0.541 & 1 & 0.541 & 0.543 & 0.010 \\
\hline Age Group X Order & 1.690 & 1 & 1.690 & 1.697 & 0.030 \\
\hline Gender X Order & 1.719 & 1 & 1.719 & 1.726 & 0.030 \\
\hline Age Group X Gender X Order & 2.424 & 1 & 2.424 & 2.433 & 0.042 \\
\hline Error & 54.793 & 55 & 0.996 & & \\
\hline \multicolumn{6}{|l|}{ Within-Subjects Effects } \\
\hline Task & 0.002 & 1 & 0.002 & 0.004 & 0.000 \\
\hline Task X Age Group & 12.724 & 1 & 12.724 & $18.378^{* *}$ & 0.250 \\
\hline Task X Gender & 0.015 & 1 & 0.015 & 0.022 & 0.000 \\
\hline Task X Order & 0.152 & 1 & 0.152 & 0.220 & 0.004 \\
\hline Task X Age Group X Gender & 0.233 & 1 & 0.233 & 0.336 & 0.006 \\
\hline Task X Age Group X Order & 0.001 & 1 & 0.001 & 0.001 & 0.000 \\
\hline Task X Gender X Order & 0.003 & 1 & 0.003 & 0.005 & 0.000 \\
\hline Task X Age Group X Gender X Order & 1.063 & 1 & 1.063 & 1.535 & 0.027 \\
\hline Error & 38.080 & 55 & 0.692 & & \\
\hline
\end{tabular}

$* \mathrm{p}<.05, * * \mathrm{p}<.01$

Note: Partial Eta ${ }^{2}$ represents the estimated amount of variance in the learning task accounted for by each respective effect in the table. 
performed the older adults on the paired-associate learning task $(\underline{t}(61)=-4.894, \underline{p}<.01)$. The results due to the interaction confirmed that older adults' learning was enhanced by a learning task that emphasizes the pragmatics of cognition and provides a rich context $(\underline{t}(60)=-2.977, \underline{p}<$ .01).

Correlation and regression analyses were conducted to determine the degree of importance of age and other associated variables in the vocabulary learning process. Correlations between learning task scores and the predictor measures are presented in Table 3. In support of expectations, the predictor measures thought to indicate mechanics, alphabetic span and reading span, were positively correlated with scores on the paired-associate learning task. As reported earlier, contrary to original assumptions, the Letter Sets test correlated with the paired-associate task score, not the vocabulary-in-context task score. It was therefore included with the measures of mechanics in further analyses. Those tasks thought to measure pragmatics, WAIS-R vocabulary subtest and synonym test scores, were positively correlated with scores on the vocabulary-in-context learning task. In addition, the pragmatic tasks did not significantly correlate with the paired-associate task scores, nor did the mechanics tasks significantly correlate with vocabulary-in-context performance. This pattern of correlations also lends construct validity to the learning tasks.

A series of hierarchical multiple regression models using the five predictors and the standardized scores on the learning tasks, separately, were calculated to determine the variance accounted for in each learning task by the various intelligence measures. The hierarchical method was chosen to determine the increment of variance due to the selected intelligence measures. Predictors were selected based on the pattern of correlations with the learning tasks, as well as the theoretical basis of mechanics and pragmatics of cognition. The paired-associate 
Figure 1. Learning Task Performance as a Function of Age

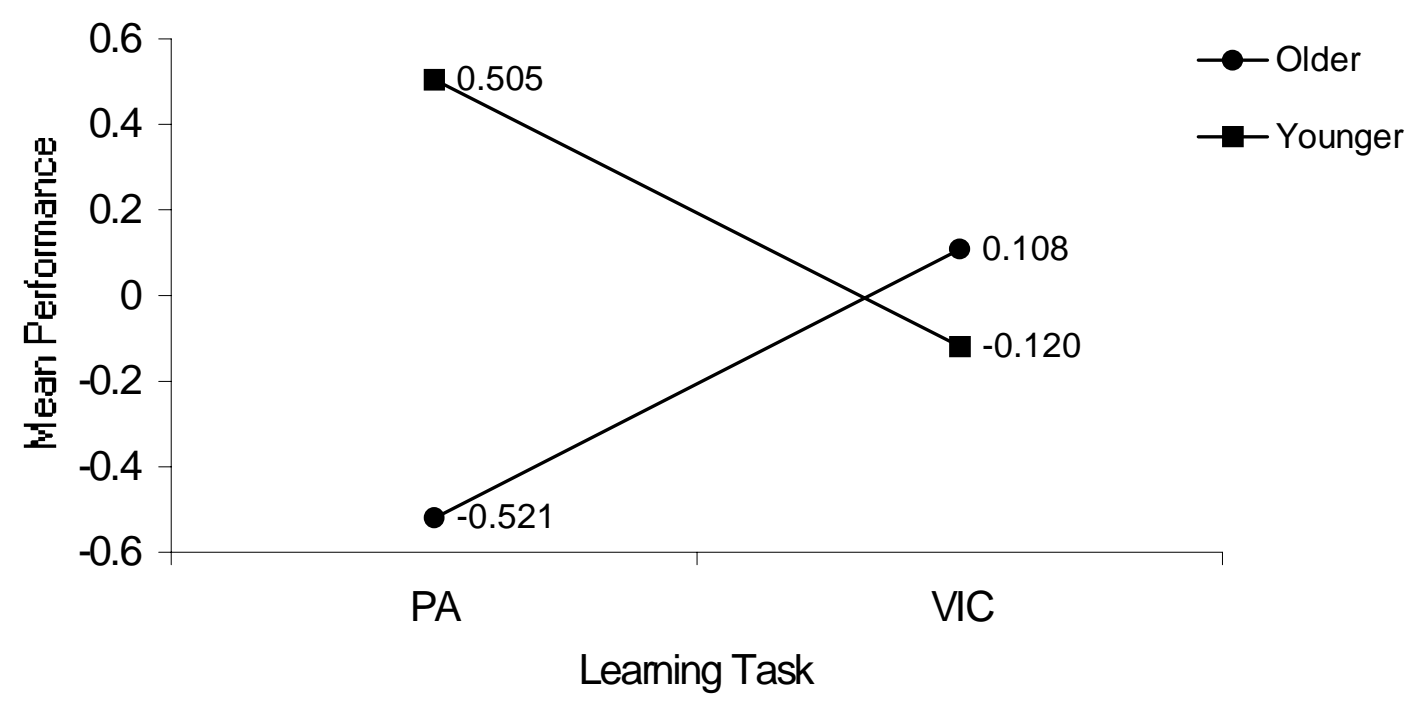


Table 3. Correlations Between Learning Tasks and Predictor Measures

\begin{tabular}{|c|c|c|c|c|c|c|c|}
\hline & PA Score & $\begin{array}{c}\text { Alphabetic } \\
\text { Span }\end{array}$ & $\begin{array}{c}\text { Reading } \\
\text { Span }\end{array}$ & $\begin{array}{l}\text { Letter } \\
\text { Sets }\end{array}$ & $\begin{array}{l}\text { VIC } \\
\text { Score }\end{array}$ & $\begin{array}{c}\text { WAIS-R } \\
\text { Vocab. }\end{array}$ & $\begin{array}{c}\text { Synonym } \\
\text { Test }\end{array}$ \\
\hline PA Score & 1.000 & $.429^{* *}$ & $.499^{* *}$ & $.492^{* *}$ & 0.168 & 0.046 & -0.043 \\
\hline Alphabetic Span & $.429^{* *}$ & 1.000 & $.380^{* *}$ & $.437^{* *}$ & 0.156 & 0.041 & -0.067 \\
\hline Reading Span & $.499^{* *}$ & $.380^{* *}$ & 1.000 & $.445^{* *}$ & 0.228 & 0.056 & 0.01 \\
\hline Letter Sets & $.492^{* *}$ & $.437^{* *}$ & $.445^{* *}$ & 1.000 & 0.221 & 0.083 & -0.136 \\
\hline VIC Score & 0.168 & 0.156 & 0.228 & 0.221 & 1.000 & $.475^{* *}$ & $.346^{* *}$ \\
\hline WAIS-R Vocab. & 0.046 & 0.041 & 0.056 & 0.083 & $.475^{* *}$ & 1.000 & $.738^{* *}$ \\
\hline Synonym Test & -0.043 & -0.067 & 0.01 & -0.136 & $.346^{* *}$ & $.738^{* *}$ & 1.000 \\
\hline
\end{tabular}


models are presented in Table 4. The models for vocabulary-in-context are presented in Table 5. As expected, the mechanics tasks (alphabetic span, reading span, and Letter Sets), entered as one block, accounted for more variance in the paired-associate learning task than in the vocabularyin-context task. On the contrary, existing vocabulary test scores (WAIS-R and synonyms), entered as one block, accounted for more variance in the vocabulary-in-context task than in the paired-associate task. Finally, the continuous age variable was entered last into each regression model. Although the measures of mechanics accounted for significant variance in the pairedassociate task, there was significant additional variance of $8.8 \%(\underline{p}<.05)$ due to age that was not captured by the predictor measures in the paired-associate models.

\section{Discussion}

The results confirmed the predictions concerning relationships between different classifications of cognition and age. Older adults displayed higher scores on tests of pragmatics of cognition than younger adults. That is, the older participants had higher scores on the measures of existing vocabulary knowledge, the WAIS-R vocabulary subtest and the synonym test. Conversely, younger adults scored higher on tests of mechanics of cognition than older adults, as measured with working memory tasks. The younger participants did better on the alphabetic span and the reading span tasks. Again, the results of the Letter Sets test were interesting. Originally it was thought that inductive reasoning would be related to the inference skill assumed to underlie the participants' strategy used to extract word meanings in the vocabulary-in-context task. However, inductive reasoning has traditionally been considered part of cognitive mechanics (Baltes, 1993). Given that consideration, the fact that the Letter Sets test was highly correlated with the other measures of mechanics (working memory span tasks), and that younger participants' scores on this task were higher, is more sensible. 
Table 4. Hierarchical Regression Models of Performance on Paired-Associate Task with Predictors Added at Each Step

\begin{tabular}{|c|c|c|c|c|c|c|}
\hline Step & Predictors & Cumulative $\mathrm{R}^{2}$ & $\mathrm{R}^{2}$ Change & F Change & $\mathrm{df}_{1}$ & $\mathrm{df}_{2}$ \\
\hline 1 & $\begin{array}{l}\text { WAIS-R Voc. } \\
\text { Synonyms }\end{array}$ & 0.031 & 0.031 & 0.886 & 2 & 56 \\
\hline 2 & $\begin{array}{l}\text { Alpha Span } \\
\text { Reading Span } \\
\text { Letter Sets }\end{array}$ & 0.320 & 0.289 & $7.499^{* *}$ & 3 & 53 \\
\hline 3 & Age (in mos.) & 0.408 & 0.088 & $7.753^{*}$ & 1 & 52 \\
\hline
\end{tabular}


Table 5. Hierarchical Regression Models of Performance on Vocabulary-In-Context Task with Predictors Added at Each Step

\begin{tabular}{|c|c|c|c|c|c|c|}
\hline Step & Predictors & Cumulative $\mathrm{R}^{2}$ & $\mathrm{R}^{2}$ Change & F Change & $\mathrm{df}_{1}$ & $\mathrm{df}_{2}$ \\
\hline 1 & $\begin{array}{l}\text { Alpha Span } \\
\text { Reading Span } \\
\text { Letter Sets }\end{array}$ & 0.072 & 0.072 & 1.450 & 3 & 56 \\
\hline 2 & $\begin{array}{l}\text { WAIS-R Voc. } \\
\text { Synonyms }\end{array}$ & 0.249 & 0.177 & $6.362^{* *}$ & 2 & 54 \\
\hline 3 & Age (in mos.) & 0.273 & 0.024 & 1.763 & 1 & 53 \\
\hline
\end{tabular}


Contrary to original hypotheses, older adults did not perform significantly better than younger adults on the vocabulary-in-context task. However, in support of original predictions, younger adults did display higher learning scores on the paired-associate task. Also, the expected interaction was significant, showing that older adults' learning scores increased more than the younger adults' in the conditions of the vocabulary-in-context task. Presumably, one reason for this interaction is that the vocabulary-in-context task was designed in such a way as to reduce the constraints on cognitive mechanics which are present in other verbal learning tasks. So the older adults were able to take advantage of the information present in the passage context, rather than relying on their working memory. The passages contained more "environmental support" than paired-associate tasks (Craik, 1986).

The correlational findings also supported the assumptions. The tasks of mechanics of cognition, alphabetic span and reading span, were significantly correlated with the pairedassociate task and conversely, the tests of pragmatics of cognition, WAIS-R subtest and synonym test, were significantly correlated with the vocabulary-in-context task. Additional construct validity was evidenced by the fact that the mechanics tasks did not correlate with vocabulary-in-context, nor did the pragmatics tasks correlate with paired-associate. Regression analyses also confirmed expectations. Mechanics, as measured by two working memory tasks and an inductive reasoning task, accounted for significant variance in the paired-associate task, but not in the vocabulary-in-context task. Also, pragmatics, as measured by two vocabulary knowledge tasks, accounted for significant variance in the vocabulary-in-context task, but not in the paired-associate task.

This investigation provides more evidence to the idea that the learning process is different across the adult life-span. Older and younger adults appear to use different resources for 
learning. It looked as though younger adults relied more on their mechanics of cognition. Because of this it is not surprising that they performed so well on the paired-associate task, which significantly correlated with the measures of mechanics. Older adults scores on tests of mechanics of cognition were not as high, and they did not perform as well on the pairedassociate task. Therefore, it is also not surprising that past verbal-learning researchers, using paired-associate tasks that rely heavily on mechanics, report age differences. This did not indicate, however, that older adults cannot learn. The fact that older adults' learning was enhanced under contextually rich task conditions suggests that they relied on a different resource than the younger adults. Based on Baltes' model and the regression results, it appeared that older adults were compensating for compromising mechanics by utilizing their strong vocabulary knowledge and past experience to perform well on the vocabulary-in-context task (Salthouse, 1988).

Although the majority of the hypotheses were confirmed, this investigation was not without certain shortcomings. Firstly, Laumann's (1996) result that older adults performed better than younger adults on a vocabulary-in-context task was not confirmed. Surprisingly, the younger participants in this investigation performed statistically as well as the older participants on the vocabulary-in-context, whereas in the 1996 study they did not score as high. Demographic characteristics, as well as performance on the predictor measures, of the samples in the two studies were virtually identical. The only difference in this version of the task was that there were fewer words to be defined (i.e., fewer passages to read). Perhaps, participants need more experience within the task (i.e., more words and passages) in order for the age differences to be significant. Moreover, the difference of the sample sizes between the two studies may have been 
sufficient enough to pick up effects. Eighty participants engaged in the vocabulary-in-context task in the 1996 study, whereas only 64 participated in this investigation.

Also, the regression models did support predictions, in that mechanics accounted for significant variance in paired-associate and pragmatics accounted for significant variance in vocabulary-in-context. However, age was also a significant predictor for performance on the paired-associate task. That is, age accounted for an additional significant amount of variance in paired-associate performance, beyond mechanics. Apparently, there is another age-related resource significant in predicting learning on the paired-associated task that was not measured. Salthouse (1993) argues that speed of processing accounts for a large amount of age-related variance on most verbal ability tasks. The Letter Sets test was the only timed measure included in this investigation. It was also entered into the regression model as one of the mechanics predictors, but significant variance remained unaccounted for by all these predictor measures of the paired-associate task. However, a direct measure of processing speed was not included in this investigation, so perhaps this variance could not be captured according to Salthouse's argument .

Furthermore, perhaps the way the constructs of mechanics and pragmatics were measured left much unaccounted variance. The most simple version of the reading span test (Daneman \& Carpenter, 1980) was used in this study. Participants were only asked to read the next sentence aloud while maintaining the last words for repetition at the end of each set. Other researchers have found more prominent age differences using more taxing versions of this task, such as requiring participants to answer questions about the content of sentences in addition to holding last words in memory (Salthouse \& Babcock, 1991). Perhaps, additional, or more discriminative, measures of working memory are needed to accurately measure the construct of mechanics. Also, the Letter Sets test was included as a measure of pragmatics because inductive reasoning 
was thought to be related to the inference skill so integral to the vocabulary-in-context task. However, the Letter Sets induction task is based on symbolic stimuli, whereas the vocabulary-incontext task includes phonologically meaningful, elaborate context cues to word meanings, so it was not tapping the inference skill. More precise measures of this inference skill should be considered in future research.

In addition to the tasks used to measure the constructs, the particular characteristics of this sample limit the generalizability of these findings. Older adults in this study were highly educated, presumably because they reside in a small, university town. The older participants and younger participants amount of education also did not significantly differ, which is not usually the case in studies of intelligence in adulthood (Schaie \& Willis, 1996), although it provided a nice control. It would be interesting to expand this investigation to include additional comparison groups such as: older adults from more urban, or more rural, areas, younger adults not enrolled in college, and adults in varying occupational pursuits.

The conclusions of this study are encouraging for older adults and those who work with older adults. Given certain conditions, like a rich context that focus on older adults' strengths, for example prior knowledge, new information can be acquired. Also, using more ecologically valid tasks, like reading passages, appears to be more beneficial for older adults' learning than rote memorization like that stressed in a paired-associate task and other traditional laboratory tasks (Hess \& Pullen, 1996). This information is potentially useful for those working on cognitive training and instruction targeted toward older individuals (Willis, 1987; Willis, 1990). Further research into situated learning and designing other task conditions that are favorable for older adults to acquire new information is needed. 


\section{References}

Arenberg, D., \& Robertson-Tchabo, E. A. (1977). Learning and aging. In J. E. Birren \& K. W. Schaie (Eds.), Handbook of the psychology of aging (pp. 421-449). New York: Van Nostrand Reinhold.

Baddeley, A. D. (1981). The concept of working memory: A view of its current state and probable future development. $\underline{\text { Cognition, }} \underline{10}, 17-23$.

Baltes, P. B. (1993). The aging mind: Potential and limits. The Gerontologist, 33, 580594.

Brown, J. S., Collins, A., \& Duguid, P. (1989). Situated cognition and the culture of learning. Educational Researcher, $\underline{18}, 32-41$.

Bowles, N. L. (1994). Age and rate of activation in semantic memory. Psychology and Aging, $\underline{9}, 414-429$.

Cavanaugh, J. (1997). Adult development and aging. Belmont, CA: Wadsworth, Brooks/Cole.

Craik, F. I. M. (1977). Age differences in human memory. In J. E. Birren \& K. W. Schaie (Eds.), Handbook of the psychology of aging (pp. 384-420). New York: Van Nostrand Reinhold. Craik, F. I. M. (1986). A functional account of age differences in memory. In F. Klix \& H. Hagendorf (Eds.), Human memory and cognitive capabilities, mechanisms, and performance (pp. 409-422). Amsterdam: North Holland: Elsevier.

Craik, F. I. M., \& Jennings, J. M. (1992). Human memory. In F. I. M. Craik \& T. A. Salthouse (Eds.), Handbook of aging and cognition (pp. 51-110). Hillsdale, NJ: Erlbaum. 
Craik, F. I. M., \& Rabinowitz, J. C. (1984). Age differences in the acquisition and use of verbal information: A tutorial review. In H. Bouma \& D. Bouwhuis (Eds.), Attention and performance X: Control of language processes (pp. 471-499). Hillsdale, NJ: Erlbaum.

Craik, F. I. M., Morris, R. G., \& Gick, M. L. (1990). Adult age differences in working memory. In G. Vallar \& T. Shallice (Eds.), Neuropsychological impairments of short-term memory (pp. 247-267). Cambridge: Cambridge University Press.

Daneman, M., \& Carpenter, P. A. (1980). Individual differences in working memory and reading. Journal of Verbal Learning and Verbal Behavior, 19, 1-25.

Daneman, M., \& Green, I. (1986). Individual differences in comprehending and producing words in context. Journal of Memory and Language, 25, 1-18.

Dobbs, A. R., \& Rule, B. G. (1989). Adult age differences in working memory. Psychology and Aging, 41, 500-503.

Ekstrom, R. H., French, J. W., Harman, H. H., \& Derman, D. (1990). Manual for kit of factor-referenced cognitive tests 1976. Princeton, NJ: Educational Testing Service.

Friendly, M., Franklin, P. E., Hoffman, D., \& Rubin, D.C. (1982). The Toronto word pool: Norms for imagery, concreteness, orthographic variables, and grammatical usage for 1,080 words. Behavior Research Methods \& Instrumentation, 14, 375-399.

Gardner, E. F., \& Monge, R. H. (1977). Adult age differences in cognitive abilities and educational background. Experimental Aging Research, $\underline{3}$, 337-383.

Gick, M. L., Craik, F. I. M., \& Morris, R. G. (1988). Task complexity and age differences in working memory. Memory and cognition, $\underline{16}$, 353-361. 
Hess, T. M., \& Pullen, S. M. (1996). Memory in context. In F. Blanchard-Fields \& T. Hess (Eds.), Perspectives on cognitive change in adulthood and aging (pp. 387-427). New York: McGraw-Hill.

Hultsch, D. F., \& Dixon, R. A. (1990). Learning and memory in aging. In J. E. Birren \& K. W. Schaie (Eds.), Handbook of the psychology of aging ( $3^{\text {rd }}$ ed., pp. 259-274). New York: Academic Press.

Kaufman, A. S. (1990). Assessing adolescent and adult intelligence. Boston: Allyn \& Bacon.

Kaufman, A. S., Reynolds, C. R., \& McLean, J. E. (1989). Age and WAIS-R intelligence in a national sample of adults in the 20- to 74-year age range: A corss-sectional analysis with education level controlled. Intelligence, $\underline{13}$, 235-253.

Kausler, D. H. (1991). Experimental psychology, cognition, and human aging. New York: Springer-Verlag.

Kausler, D. H., \& Puckett, J. M. (1980). Frequency judgments and correlated cognitive abilities in young and elderly adults. Journal of Gerontology, 35, 376-382.

Laumann, L. L. (1996). Adult age differences in vocabulary acquisition. Unpublished master's thesis, West Virginia University, Morgantown.

Light, L. L. (1991). Memory and aging: Four hypotheses in search of data. Annual Review of Psychology, 44, 333-376.

Light, L. L., \& Anderson, P. A. (1985). Working-memory capacity, age, and memory for discourse. Journal of Gerontology, $\underline{40}, 737-747$.

Miller, G. A., \& Gildea, P. M. (1987). How children learn words. Scientific American, 257, 94-99 
Park, D. C., \& Shaw, R. J. (1992). Effect of environmental support on implicit and explicit memory in younger and older adults. Psychology and Aging, 7, 632-642.

Reese, H. W. (1997). Counterbalancing and other uses of repeated-measures Latin-square designs: Analyses and interpretations. Journal of Experimental Child Psychology, 64, 137-158.

Salthouse, T. A. (1982). Adult Cognition. New York: Springer-Verlag.

Salthouse, T. A. (1988). Effects of aging on verbal abilities: Examination of the psychometric literature. In L. L. Light \& D. M. Burke (Eds.), Language, memory, and aging (pp. 17-35). Cambridge: Cambridge University Press.

Salthouse, T. A. (1991). Theoretical perspective on cognitive aging. Hillsdale, NJ: Erlbaum.

Salthouse, T. A. (1993). Speed and knowledge as determinants of adult age differences in verbal tasks. Journal of Gerontology: Psychological Sciences, $\underline{48}$, P29-P36.

Salthouse, T. A., \& Babcock, R. L. (1991). Decomposing adult age differences in working memory. Developmental Psychology, 27, 763-776.

Salthouse, T. A., Babcock, R. L., \& Shaw, R. J. (1991). Effects of adult age on structural and operational capacities in working memory. Psychology and Aging, $\underline{6}, 118-127$.

Salthouse, T. A., Kausler, D. H., \& Saults, J. S. (1988). Investigation of student status, background variables, and feasibility of standard tasks in cognitive aging research. Psychology and Aging, $\underline{3}, 29-37$.

Schaie, K. W., \& Willis, S. L. (1996). Psychometric intelligence and aging. In F. Blanchard-Fields \& T. Hess (Eds.), Perspectives on cognitive change in adulthood and aging (pp. 293-322). New York: McGraw-Hill. 
Service, E., \& Craik, F. I. M. (1993). Differences between young and older adults in learning a foreign vocabulary. Journal of Memory and Language, $\underline{32,}$ 608-623.

Smith, A. D., \& Earles, J. L. K. (1996). Memory changes in normal aging. In F.

Blanchard-Fields \& T. Hess (Eds.), Perspectives on cognitive change in adulthood and aging (pp. 192-220). New York: McGraw-Hill.

Sternberg, R. J. (1987). Most vocabulary is learned from context. In M. G. McKeown, \& M. E. Curtis (Eds.), The nature of vocabulary acquisition (pp. 89-105). Hillsdale, NJ: Erlbaum. Sternberg, R. J., \& Powell, J. S. (1983). Comprehending verbal comprehension.

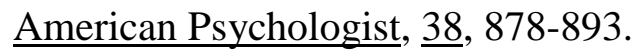

Wechsler, D. (1981). Manual for the Wechsler Adult Intelligence Scale--Revised. San Antonio, TX: The Psychological Corporation.

Willis, S. L. (1987). Cognitive interventions in the elderly. In K. W. Schaie (Ed.), Annual review of gerontology and geriatrics (vol. 7, pp. 159-188). New York: Springer.

Willis, S. L. (1990). Current issues in cognitive training research. In E. A. Lovelace (Ed.), Aging and cognition: Mental processes, self-awareness, and interventions (pp. 263-280). New York: North-Holland.

Wingfield, A., Stine, E. A. L., Lahar, C. J., \& Aberdeen, J. S. (1988). Does the capacity of working memory change with age? Experimental Aging Research, $\underline{14}, 103-107$. 
Appendix A: Passages and Novel Words Used in Vocabulary-in-Context Task 
As the election approached, George Adams appeared to be moving closer towards a probable victory. However, probable victories were not valued by George Adams. He was a man who dealt only with certainties. To achieve this he would stop at nothing. People saw him as unscrupulous and shrewd. However, he had not always been this way. Somewhere along the line in his career he had learned that you had to fight your way to the top and since then there had been no turning back. He showed little concern for the victims of his schemes. He had nothing personal against John Mead. He merely saw the destruction of this man's career as a necessary step in furthering his own career. To accomplish this he decided a roorback would serve him well. He had knowledge that John Mead had at one time gone to see a psychiatrist. This information George Adams carefully disclosed at an informal gathering of friends. He omitted to mention that the psychiatrist had been a friend of John Mead's and that Mead had only asked the psychiatrist for advice on a financial matter. George Adam's version of the truth, however, had grave implications. A week later, upon being told his own story by one of his new supporters, George Adams grinned silently to himself. He was now a step closer to his goal.

roorback: A dirty rumor which is used against a political opponent 
Joan had been lying out on the beach all afternoon. She had come outside soon after lunch and had started to look for a good spot. She soon found one -- secluded and quiet, with a good view of the rocks and the water, but with a little bit of privacy as well. She had taken her lotion, her book, and her towel, and had settled herself comfortably. This was her first day of vacation and she intended to relax. She had planned to spend a few hours on the beach and then return to the house to get ready for the party that night. But she had fallen asleep and stayed out longer than she had intended, and now she was worried. When she got inside she saw that the worry was justified. She put cream on her face and shoulders and hoped for the best. But when she woke up the next morning, she saw a number of patches of blype on her pillow. She ran to the mirror, but this only confirmed what she had expected. She knew that she would look terrible for days to come if she did nothing about it, so she decided to sit out in the sun a little each day in the hopes that an improvement would result. Even if it worked, it was a depressing and unfortunate start to her holidays.

blype: A piece of skin that peels off after a sunburn 
Mike had picked up his license the day before. Then he had packed and prepared all evening. He had made sure that he had enough food and clothing to last him for five days, as well as all the first aid supplies he might possibly need. Then he had checked his equipment. Satisfied, he had gone to bed. Arising early the next morning, he climbed into his car and drove north. Twelve hours later he arrived at his destination. He was surprised at how energetic he felt, considering the long day he'd just had. He didn't feel tired at all. He opened up the cabin and unpacked everything. After a late supper, he checked his equipment. He was eager to get started. This was something he did for enjoyment and not for the food it provided, and he looked forward to that enjoyment. Mike felt restless and impatient, unable to wait. He knew that it would be dangerous to go out now. He would not be able to clearly distinguish what he was aiming at or where he was going. But he decided to go anyway. He would rather ghoom than wait until the normal starting time. He gathered all the necessary equipment and went outside. He felt very happy as he started on his way. But soon he began to feel uncertain of the direction he was going, and unsure of his footing. He decided that, after all, this was not such a good idea, and he turned back.

ghoom: To hunt in the dark 
Jackie stared ahead incredulously. Here she was face to face with Ken Smith for the first time after a four year separation. They had run into each other on campus quite accidently, neither of them even suspecting that they were both attending the same university in London. They were thrilled by their reunion. As teenagers they had been neighbors. Jackie and Ken shared a very special relationship and had wanted to get married at the time. However, both their parents disapproved. When Ken's father got a promotion which entailed moving to Philadelphia, both families saw this as a lucky break. Their parents thwarted any efforts they made to keep in touch. Jackie believed that nothing could stand in the way of the type of closeness she and Ken had shared. She believed that a simple reunion would be sufficient to re-establish this closeness. Jackie continued to dream up ways to reunite herself with Ken -- none of which worked. Fate, however, provided her with what she hoped would be an anacampserote. It was ironic that her parents should unwittingly help to bring this about. Jackie had never wanted to continue her education beyond high school and had only gone to university upon the insistence of her parents. Had she not attended university she would perhaps never have been permitted the opportunity to re-establish her relationship with Ken. Jackie could not believe how lucky she had been. anacampserote: Something which can bring back a lost love 
Rick, Eliza, and Daisy were walking through the pasture. All around them were cornfields and more pastures, and off in the distance stood a barn and a house. They headed in that direction. Rick and Eliza talked animatedly to each other and ignored Daisy, but she didn't seem to notice, shambling along behind them, munching at the grass as she went. Finally they neared the edge of the pasture. Without pausing, Rick and Eliza went through the grike. They continued on to the house, still talking happily, but Daisy could no longer follow, and this disturbed her. She wanted to go with them. She tried to walk through as well, but found that she could not. She looked for another exit, but found none. All around her was a thick impregnable barrier. She stared unhappily around her for a few minutes, but she soon forgot what had upset her, and she turned her attention once again to food. She turned around and, moving slowly as she usually did, went to join the others of her own kind and spend yet another night in the pasture. Maybe Rick and Eliza would come back the next day to see her.

grike: A narrow opening in a fence that allows people through but does not allow farm animals through 
Janet had always managed to keep in touch with her high school friends. Whenever she came home for a weekend in Pittsburgh she would call up her friends who were still in town. It distressed her that she had been unable to get in touch with her friend, Linda. Each time she had called, the phone was either busy or there was no answer. So, when she returned to Chicago, she set aside a few minutes during a coffee break at work so that she could finally get in touch with her friend. With pen and paper in hand she set to work. Within a matter of minutes she was licking the stamps and off it went. Several days went by and Janet was disappointed not to have heard from her friend. The following day she picked up her mail and quickly sorted through it in the hope of finding something from Linda. But, there was nothing from Linda. To her surprise though she discovered the reason for Linda's delay in response. Linda had yet to hear from Janet. Janet went off to the typewriter to set things straight. She placed the nixie in the newly typed envelope. This way Linda would know that Janet had in fact mailed it earlier. Had it not been for the typed label she had placed on the left hand corner originally, Janet might still be wondering why she had not heard back from Linda. "Oh well," Janet sighed, "at least this time I will finally be able to contact Linda."

nixie: A letter so badly addressed that it cannot be delivered 
Robert had been here for ten years. He had been a construction worker before, with a wife and two kids, but he hadn't been happy with that. And so he had taken a risk, hoping that his dishonest actions would improve his situation. But things hadn't worked out, he had been caught, and he had ended up here. There were a lot of things he missed -- the ability to go where he wanted, the company of his family. He disliked it, but he had learned to live with it. In some ways, he recognized that he deserved it. And things weren't all bad. There were ways to get some of the things he enjoyed, things that he wasn't supposed to have. He always had a pack of cigarettes and a bottle of whiskey stashed away among his things. He used the chummage to get these things. Men were almost always reluctant to give this to him, but they recognized the need to have someone who would help them learn the ropes, and so they agreed. He was usually valuable to them for at least two weeks, by which time they had learned enough about the way things were done to survive on their own. And there were always quite a few of them being brought in to live there. He suspected that the authorities knew what was going on but ignored it because they were helpless to stop it. He could have made quite a profit if he hadn't enjoyed his vices so much.

chummage: Money demanded by an old prisoner of new ones 
Tom was exhausted. Coming home after a long, hard swimming practice he headed straight for his room with the intention of taking a short nap. In spite of the sun shining in from the window overhead he fell asleep quite easily. Soon, however, his parents, who had just returned from shopping, woke him up. Tom looked up and sleepily viewed his parents, as they moved his new desk into his room. Mrs. Johnson, after stepping back to look at the desk, suggested moving it closer to the window so that Tom would get the maximum amount of light. Tom remarked that then they would have to eliminate the ruelle and he didn't want to do that. Mrs. Johnson said that she didn't see why this should make such a big difference. "Besides," she added, "then you won't be able to get up on the wrong side in the morning." Tom said he liked being able to sleep with his legs hanging over the edge on either side. He finally gave in saying that he could probably get used to the change. Tom got up and they made the necessary moves. After all the commotion Tom was wide awake. Rather than returning to finish his nap he decided to put his things into the new desk.

ruelle: A space between the bed and the wall 
Cecilia, Tracy, and Sonja weren't the closest of friends. It would have seemed odd to anyone who knew these three to see them sitting at a table together at 'Mingles'. In fact these three girls rarely had any time to spare to talk to other women. They tended to view them as the 'enemy'. Yet, here they were on a Saturday night at 'Mingles'. They were disappointed to say the least. Usually these girls would have spent the evening dancing and having their drinks bought for them. They never had any difficulty in attracting a fair deal of attention. Their conversation tonight remained at a shallow level as each anxiously waited for things to pick up. Then they would go their own ways without the slightest regard for each other. Their present boredom was their own fault though. The deciding game of the AFC Conference Championship finals was on tonight. Had they remembered this earlier they could have anticipated the spaneria and shown up later. But as it was they had to carry on an awkward conversation while desperately waiting for the game to end.

spaneria: Scarcity of men 
The teacher finally managed to break up the fight. She looked at the two boys. John had fallen hard on the pavement and scraped his arm, and it was bleeding badly. Mark had taken a punch in the face that must have hurt a lot. It looked like he was having trouble breathing. He probably couldn't smell anything anymore. And there was a lot of blood. The teacher took them both in to the school nurse. The nurse looked at Mark first, and assured him that nothing was broken. She cleaned the wound carefully. Because the bleeding hadn't stopped, she decided to do something more, both to stop the bleeding and to keep the wound from getting infected. When she was finished, Mark looked at himself in the mirror and complained that he looked ridiculous. But he promised to leave it on for two days. Then he left. The nurse then asked John to come in, and she worked on his arm. Again she needed to apply something to stop the bleeding. When John went outside he looked around for Mark. The other kids were busy teasing Mark, and when John came out they started teasing him too. He replied that his arm might look funny, but at least he didn't have to get an accipiter like Mark's. Covering his face to hide the thing that John had teased him about, Mark ran home. His mother scolded him for fighting, but didn't send him back to school.

accipiter: A bandage worn around the nose 
Appendix B: Demographic Questionnaire 
1. Your age in years and months:

2. Your sex: $M$ F

3. Years of formal schooling: (H.S. = 12)

4. Please rate your health (1=excellent, $5=$ =poor): $\begin{array}{lllll}1 & 2 & 3 & 4 & 5\end{array}$

5. What is your native language? That is, what language was spoken in your home when you were a child?

If your native language is not English, at what age did you learn English?

Do you speak, write or read any other languages?

6. Please list any medication you are now taking, and the time you last took them. Consider these categories: Antihypertensives

Analgesics
Antidiarrheals
Sedatives
Others

Antibiotics

Cough/cold

Laxatives

Antidepressants

7. How much do health troubles stand in the way of your doing things you want to do? Circle one.
Not at all
A little (some)
A great deal

8. Do you think that your health is better, the same as, or worse than most people your age?

Much better Better The same Worse Much worse

9. Are you currently retired or are you still working?

Student Working Homemaker Unemployed Retired

If you are retired, when did you retire?

10. Please rate the amount of reading you do in a normal week:

$$
\text { (1=a lot, 5=little or none): } \quad \begin{array}{lllll}
1 & 2 & 3 & 4 & 5
\end{array}
$$

11. Please indicate what types of materials you read.

12. Please rate how challenging and/or technical your reading materials are (1=very challenging, $5=$ =easy reading): $1 \begin{array}{lllll}1 & 2 & 3 & 4 & 5\end{array}$ 
Appendix C: Paired-Associate word pairs and orders 


\section{$\underline{\text { Paired Associate Word Pairs and Order }}$}

\section{$\underline{\text { Trial One }}$}

dippoldism -- shortage

lagniappe - gallop

holmgang - merchandise

ucalegon - longevity

agio - ballroom

apocope - compliant

groak - relish

grangerism - radish

qualtagh - handicap

benedick - spectator

Trial Three

dippoldism - shortage

grangerism - radish

holmgang - merchandise

agio - ballroom

benedick - spectator

ucalegon - longevity

groak - relish

apocope-compliant

lagniappe - gallop

qualtagh - handicap

\section{Trial Two}

lagniappe - gallop

agio - ballroom

ucalegon - longevity

groak - relish

dippoldism - shortage

qualtagh - handicap

grangerism - radish

benedick - spectator

holmgang - merchandise

apocope - compliant

$\underline{\text { Trial Four }}$

ucalegon - longevity

benedick - spectator

groak - relish

dippoldism - shortage

homgang - merchandise

agio - ballroom

qualtagh - handicap

apocope-compliant

grangerism - radish

lagniappe - gallop 
Appendix D: Vocabulary-In-Context Scoring Manual 
1. Roorback A dirty rumor (1) which is used against a political opponent (2); 1 point given for rumor, gossip, white lie or politics, elections

Zero-point answers:

Planning or scheme

Giving part of information to purposely mislead someone

Something sent out to be circulated

Unscrupulous behavior

Stepping stone

Scandalous

One-point answers:

Political "backhand"

Rumor

Mud slinging

A slanderous remark about someone

Dirty gossip

Two-point answers:

Rumor to stab political opponent in back

Telling half-truths about other political candidates

2. Blype A piece of skin (1) that peels off after a sunburn (2); 1 point given for skin or sun

Zero-point answers:

Goo, melted cream, cosmetics

Pus from blisters

Oozing liquid

A secretion

Dried, creamy blotches

White spots

One-point answers:

Sunburn, discomfort from being in sun

Skin from blisters

Flakes, peelings, patches, or pieces of skin

Water from blisters caused by sunburn

Burned, dead skin

Two-point answers:

Sunburn, peeling, skin

Peeled skin from over exposure to the sun

Sunburned skin that has fallen off

Patches of dry skin caused by the sun 
3. Ghoom To hunt (1) in the dark (2); 1 point given for the idea of hunting or for darkness, early morning, etc.

\section{Zero-point answers:}

Be ready, get a head start

Rush

Start early, ahead of time

Take a chance

To take risks

To get lost, wander

One-point answers:

Find your way in the dark

Go hunting early

Hunting (for pleasure)

Two-point answers:

Hunting in the evening shadows (not light)

Night-time hunting

To go out hunting at night

Going out hunting in the dark

Hunting, shooting in the dark

4. Anacampserote Something which can bring back (1) a lost love (2); 1 point given for the concept of vehicle or object used to get together or love, relationship

Zero-point answers:

Scheming, planning

Opportunity, possibility

Second chance

Dream

Unexpected meeting

Feeling of hope

Act of fate, circumstance

One-point answers:

Reunion

Reunited

Method of reunion

Re-establish relationship

Something to do with a love affair

Two-point answers:

An opportunity to renew old affairs 
Something to help her plans to be married to him The fate that had drawn the couple back to one another

5. Grike A narrow opening in a fence (1) that allows people through but does not allow farm animals through (2); 1 point given for the idea of an opening in a barrier (gate) or for the idea of animals being barred

Zero-point answers:

Hedge, bush

Swamp or bog, wetlands

Barrier or fence

Grassy area, meadow

Hay, weeds, or tall grass

One-point answers:

Going through the gate

Exit or opening in a fence

Gate in a fence

Narrow passageway for people to fit

Can't cross a grate-like structure

Two-point answers:

A special gate for people but will exclude large animals

Cow couldn't get over the fence and the people did

6. Nixie

A letter (1) so badly addressed that it cannot be delivered (2); 1 point for the idea of letter, note or for being returned

Zero-point answers:

excuse, explanation

copies of a previous letter

mail

return address or postmark

One-point answers:

the note, letter

wrong address on envelope

an envelope which was returned

a retyped letter

Two-point answers:

letter returned for correct address

an undelivered letter, returned to sender

incorrectly addressed letter, not deliverable 
7. Chummage $\quad$ Money (1) demanded by an old prisoner of new ones (2); 1 point given for the concept of money or prison

Zero-point answers:

dishonesty, being sly

personality

friendship, charm, "chums"

connections

using friendship to get the things he wanted

knowledge of situation where people are new

One-point answers:

other prisoners' help

spare money, change

extra money he had

people who are in prison and make friends to get favors in return

trading his expertise of jail system to get what he wanted

Two-point answers:

There were none reported.

8. Ruelle A space (1) between the bed and the wall (2); 1 point given for the idea of space, room or for side of bed

Zero-point answers:

view

bookcase, nightstand, other pieces of furniture

bed rail, or headboard

morning light from window

blinds to let in sunlight

One-point answers:

space

move bed up against the wall

personal room to move around

the space between objects in the room

Two-point answers:

space on either side of the bed

space beside the bed

space between the bed and the wall

room on both sides of his bed

walking space between his bed and the window 
9. Spaneria

Scarcity (1) of men (2); 1 point given for the idea of sparse, few or for the idea of men, customers

\section{Zero-point answers:}

the situation of being bored

the crowd

a distraction

boredom, time lapse, lifelessness

lack of activity

One-point answers:

slowing down of people, quiet time

few amount of customers in the bar

Two-point answers:

few people

scarcity of men

lull in activity, absence of people, especially men

10. Accipiter

A bandage (1) worn around the nose (2); 1 point given for the concept of bandage (compress, stop bleeding, etc.) or for the word 'nose'

Zero-point answers:

one who tries to assist or help

something, a cast, on his arm

a sting

to look ridiculous, strange, or awkward

a brace or splint on the arm

blood filled scar

stitches

One-point answers:

a medical gadget used to stop bleeding

a bandage, covering, wrap

a patch on the nose

a device used to put pressure on a body part to stop bleeding

a nose guard

broken nose, swollen puffy face

Two-point answers:

pressure bandage to stop nose bleed

some kind of bandage for his nose

a big bandage that the teacher had put on his nose 
type of bandage on the nose to stop the bleeding what you put on a person's nose to stop the bleeding 
Appendix E: Nouns Used in Alphabetic Span Task 
$\underline{\text { Three Word Sets }}$

ORGAN

PARTY

FARMER

COFFEE

ANSWER

DESIGN

$\underline{\text { Four Word Sets }}$

NEEDLE

MARKET

CHERRY

BEGGAR

HANDLE

LILY

BARREL

MARBLE

$\underline{\text { Five Word Sets }}$

POWDER

TUNNEL

SERIES

INSECT

HERO

JACKET

RECORD

PALACE

OLIVE

MAYOR

$\underline{\text { Six Word Sets }}$

JEWEL

SIGNAL

LINEN

VELVET

WEAPON

CARPET 


\section{CANVAS \\ MEMBER \\ TURKEY \\ LETTER \\ HARBOR \\ BERRY}

$\underline{\text { Seven Word Sets }}$

ELBOW
MOTOR
PONY
HONEY
BABY
LIQUOR
DIET
GARDEN
IRON
DEBATE
ENGINE
MONKEY
HELMET
CHAPEL

$\underline{\text { Eight Word Sets }}$

FINGER

NEPHEW

MOTHER

HAMMER

WAGON

BASKET

SPIDER

UNCLE

DEVICE

SYSTEM

BUTTON

PILLOW

NOVEL

METAL

ARMOR

COTTON 
Appendix F: Sentences Used in Reading Span Task 


\section{$\underline{\text { Two sentence sets }}$}

After dinner, the chef prepared dessert for her guests.

Everyone in the stadium felt cold.

The people on the airplane had never flown before.

In the library, the girl read her book.

The basketball team won the championship last year.

The woman planted pansies on her patio.

\section{Three sentence sets}

The fans at the football game wore hats and scarves.

The passengers on the train were happy.

David was going with William to the meeting.

The children in the car wanted to stop for ice cream.

Last fall the farmers had a good harvest.

The baseball player hit the ball over the fence.

The maid usually washes clothes in the afternoon.

The iron gate clanged shut.

The door that leads to the basement was locked.

$\underline{\text { Four sentence sets }}$

The cat chased the mouse through the barn.

This morning the mailman brought three letters.

The man ran up the hill.

After the movie, Tom ordered the pizza.

The sofa in the living room is green.

This evening the grocer will deliver the food.

The students planned a class reunion.

The boy put the pencils in the drawer.

A bear looks for food in the woods.

The bald eagle soared over the trees.

At the end of the day, the children counted their money.

My sister answered the lawyer's questions. 
$\underline{\text { Five sentence sets }}$

Sarah put her toys in the chest.

Frank caught a large blue fish in the river.

Mary drove her new red car to the station.

Jerry is the class president.

The ticket is good for one trip on the railroad.

Bob made his mother a wooden desk.

Susan works at the factory which produces trucks.

Last night, Carol sent invitations to her friends.

Tomorrow, Simon will bring treats for the children.

The teacher told the boy to sharpen the pencil.

Carol received a raise from her boss.

This light house is an important mark for pilots.

In the morning, Bill has a math class.

Jill knits all of her family's sweaters.

At the back of the house there is a small garage. 
Appendix G: Instructions and Examples of Words Used in WAIS-R Vocabulary Subtest 
Read aloud to participants: "I want you to tell me the meanings of some words. Let's start with ; What does mean?"

Three words on the WAIS-R subtest:
winter
designate
audacious 
Appendix H: Synonyms Test 
Synonyms Vocabulary Test

Directions: For each of the items below, select the numbered word or phrase that most nearly corresponds in meaning to the word in CAPITAL LETTERS and circle it.

CAPSIZE

PROLONG

SUCCULENT

AGITATED

FRUGAL

MOLEST

APATHY
1) leak
2) race
3) grow
4) overturn
5) measure
1) prompt
2) decrease
3) difficult
4) extend
5) waste
1) juicy
2) raw
3) cooked
4) spoiled
5) spicy
1) hungry
2) excited
3) agile
4) tired
5) sick
1) sparing
2) huge
3) tasty
4) fashionable
5) musical
1) purchase
2) muffle
3) lowest
4) annoy
5) groom
1) understanding
2) leniency
3) rage
4) indifference
5) danger
WEIGHTY
1) sly
2) serious
3) shabby
4) spry
5) innocent
FANATIC
1) follower
2) strange
3) untrustworthy
4) sly
5) zealous
BUSTLE
1) tree
2) ornament
3) bureau
4) movement
5) cluster

LASCIVIOUS

1) lustful

2) liberal

3) final

4) loser

5) inclined

RECAPITULATE
1) surrender
2) brief
3) rebuild
4) relay
5) restate

REMUNERATE

1) check

2) count

3) replete

4) compensate

5) satisfy

EFFECTUATE

1) praise

2) accomplish

3) dissimulate

4) nullify

5) pretend 


\begin{tabular}{|c|c|c|c|}
\hline BRAVADO & $\begin{array}{l}\text { 1) celebrity } \\
\text { 2) outlaw } \\
\text { 3) boasting } \\
\text { 4) turmoil } \\
\text { 5) salutation }\end{array}$ & DIAPHANOUS & $\begin{array}{l}\text { 1) nocturnal } \\
\text { 2) quarrelsome } \\
\text { 3) morbid } \\
\text { 4) logical } \\
\text { 5) ethereal }\end{array}$ \\
\hline CURSORY & $\begin{array}{l}\text { 1) hasty } \\
\text { 2) dilatory } \\
\text { 3) intrinsic } \\
\text { 4) profane } \\
\text { 5) dire }\end{array}$ & SPLEEN & $\begin{array}{l}\text { 1) grudge } \\
\text { 2) caprice } \\
\text { 3) impetuosity } \\
\text { 4) melancholy } \\
\text { 5) malice }\end{array}$ \\
\hline INDIGENT & $\begin{array}{l}\text { 1) obnoxious } \\
\text { 2) moody } \\
\text { 3) sleep } \\
\text { 4) nasty } \\
\text { 5) poor }\end{array}$ & HORDE & $\begin{array}{l}\text { 1) greed } \\
\text { 2) bully } \\
\text { 3) harvest } \\
\text { 4) crowd } \\
\text { 5) content }\end{array}$ \\
\hline LOQUACIOUS & $\begin{array}{l}\text { 1) garrulous } \\
\text { 2) ostentatious } \\
\text { 3) frivolous } \\
\text { 4) limpid } \\
\text { 5) dowdy }\end{array}$ & HIRSUTE & $\begin{array}{l}\text { 1) woman } \\
\text { 2) shaggy } \\
\text { 3) chamber } \\
\text { 4) quaint } \\
\text { 5) sorrowful }\end{array}$ \\
\hline HIATUS & $\begin{array}{l}\text { 1) break } \\
\text { 2) swamp } \\
\text { 3) fence } \\
\text { 4) disgust } \\
\text { 5) flower }\end{array}$ & CAUDAL & $\begin{array}{l}\text { 1) brutal } \\
\text { 2) careful } \\
\text { 3) posterior } \\
\text { 4) nervy } \\
\text { 5) recent }\end{array}$ \\
\hline BANAL & $\begin{array}{l}\text { 1) evil } \\
\text { 2) trite } \\
\text { 3) prohibitory } \\
\text { 4) jovial } \\
\text { 5) decaying }\end{array}$ & GUIDON & $\begin{array}{l}\text { 1) miniature } \\
\text { 2) hat } \\
\text { 3) hero } \\
\text { 4) flag } \\
\text { 5) achiever }\end{array}$ \\
\hline TEDIUM & $\begin{array}{l}\text { 1) dilatory } \\
\text { 2) anxiety } \\
\text { 3) exhaustion } \\
\text { 4) weakening } \\
\text { 5) dull }\end{array}$ & VICISSITUDE & $\begin{array}{l}\text { 1) direction } \\
\text { 2) generosity } \\
\text { 3) hardship } \\
\text { 4) ceremony } \\
\text { 5) ferocity }\end{array}$ \\
\hline LASSITUDE & $\begin{array}{l}\text { 1) contempt } \\
\text { 2) convenience } \\
\text { 3) permissiveness } \\
\text { 4) lethargy } \\
\text { 5) levity }\end{array}$ & SEVERALLY & $\begin{array}{l}\text { 1) unkindly } \\
\text { 2) respectively } \\
\text { 3) continuously } \\
\text { 4) abruptly } \\
\text { 5) harshly }\end{array}$ \\
\hline
\end{tabular}


Appendix I: Instructions for Letter Sets Test 


\section{$\underline{\text { Letter Sets Test }}$}

Each problem in this test has five sets of letters with four letters in each set. Four of the sets of letters are alike in some way. You are to find the rule that makes these four sets alike. The fifth letter set is different from them and will not fit this rule. Draw an $\mathrm{X}$ through the set of letters that is different. NOTE: The rules will not be based on the sounds of sets of letters, the shapes of letters, or whether letter combinations form words or parts of words.

Examples:
A. NOPQ

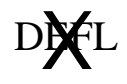
$\mathrm{ABCD}$
HIJK
UVWX
B. NLIK
PLIK
QLIK
THXK
VLIK

In Example A, four of the sets have letters in alphabetical order. An $\mathrm{X}$ has therefore been drawn through DEFL. In Example B, four of the sets contain the letter L. Therefore, an X has been drawn through THIK.

Your score on this test will be the number of problems marked correctly minus a fraction of the number marked incorrectly. Therefore, it will not be to your advantage to guess unless you are able to eliminate one or more of the letter sets.

You will be allowed 7 minutes for each of the two parts of this test. Each part has one page. When you have finished Part 1, STOP. Please do not go on to Part 2 until you are asked to do so. 


\section{Lisa L. Laumann}

Department of Psychology

West Virginia University

P.O. Box 6040

Morgantown, WV 26506-6040

(304) 293-2001 Ext. 848

E-mail: llaumann@wvu.edu
476 Protzman Street

Morgantown, WV 26505

(304) 296-3745

\section{$\underline{\text { Education }}$}

1999 Ph.D. Life Span Developmental Psychology (May, 1999), West Virginia University, Dissertation Title: Age Differences in Vocabulary Acquisition as a Function of Individual Differences in Working Memory and Knowledge Base, Stanley H. Cohen, Chair

1999 Graduate Certificate in Gerontology (May, 1999), West Virginia University

1996 M.A. Life Span Developmental Psychology, West Virginia University, Thesis Title: Adult Age Differences in Vocabulary Acquisition, Raymond J. Shaw, Chair

1992 B.A. Psychology, Summa Cum Laude, Bradley University, Peoria, IL

\section{Honors and Awards}

Recipient of Graduate Assistantships from West Virginia University, Center on Aging, Education Unit, 1996 to present

Award for Completed Research from Division 20 (Adulthood and Aging) of APA, 1996

Graduated Summa Cum Laude in Psychology, 1992

Outstanding Senior, College of Liberal Arts \& Sciences

Outstanding Senior in Psychology

Omicron Delta Kappa

Mortar Board

Psi Chi, 1991

Phi Kappa Phi

Dean's Scholarship

Dean's List, eight semesters at Bradley University

Alpha Lambda Delta

Phi Eta Sigma 


\section{Professional Affiliations}

Student Member of Gerontological Society of America, 1992-Present

Student Affiliate of American Psychological Association, 1992-Present

Student Member of Division 20, APA, Adulthood and Aging, 1993-Present

Student Member of American Society on Aging, 1992-1995

Student Member of Division 7, APA, Developmental Psychology, 1992-1993

\section{$\underline{\text { Publications }}$}

Shaw, R. J., \& Laumann, L. L. (1994). The interactions of knowing and remembering in Alzheimer's disease. West Virginia Journal of Psychological Research and Practice, $\underline{3}$, 77-86.

Shaw, R. J., \& Laumann, L. L. (1993). Neurobiological factors in the normal age-related decline of selective attention. West Virginia Journal of Psychological Research and Practice, 2, 7382.

\section{Conference Presentations}

Laumann, L. L., \& Shaw, R. J. (1996, April). Adult age differences in vocabulary acquisition. Poster presented at the Cognitive Aging Conference, Atlanta, GA.

Shaw, R. J., Huang, W., Ruther, N. M., Laumann, L. L., Keefover, R. W., \& Rankin, E. D. (1996, April). Characteristics of free recall in normal aging and Alzheimer's disease. Paper presented at the Cognitive Aging Conference. Atlanta, Georgia.

Shaw, R. J., \& Laumann, L. L. (1994, April). The roles of Working Memory and knowledge in verbal memory in Alzheimer's disease. In R. J. Shaw (chair), Medical, social, and psychological aspects of Alzheimer's disease. Symposium conducted at the Spring meeting of the West Virginia Psychological Association, Charleston, WV.

Shaw, R. J., \& Laumann, L. L. (1993, April). Neurobiological considerations in the study of normal aging. In D.W. Schaal (Chair), Biological factors in psychology. Symposium conducted at the Spring meeting of the West Virginia Psychological Association, Davis, WV.

Etaugh, C., \& Laumann, L. (1992, August). Perceiving elder caregivers: Effects of gender, employment, and caregiving hours. Poster presented at annual meeting of the American Psychological Association, Washington, D.C.

\section{Work in Progress}

Edelstein, B., Laumann, L., Kalish, K., Jones, K., Staats, N., \& Northrop, L. Role of memory in performance on the Hopemont Capacity Assessment Interview. (Data collection in progress). 
Laumann, L.L. Age differences in vocabulary acquisition as a function of individual differences in working memory and knowledge base. (Dissertation proposal approved, data analyses in progress).

Laumann, L.L., \& Shaw, R.J. Adult Age Differences in Vocabulary Acquisition. (Manuscript in preparation for review).

Shaw, R. J., Laumann, L. L., \& Ruther, N. M. General priming effects of encoding a list of words. (Data collection in progress).

\section{Research Interests}

My research interests center on cognition in later adulthood, specifically processes such as memory and information acquisition. Previous and current research topics include work on the priming phenomenon across adulthood, the development of inhibitory mechanisms, working memory in adults with dementia, the relation of memory to different dimensions of intelligence testing, reading comprehension, and vocabulary acquisition.

\section{Research Experience}

1) Served as a research assistant for Dr. Raymond Shaw on a grant from the Alzheimer's Association. Responsibilities included testing patients with varying degrees of dementia using the Geriatric Depression Scale, the Mini Mental Status Exam, and various WAIS-R subtests. I developed valuable assessment and interaction skills from this experience.

2) Interaction with many different populations during my data collection activities, including children, college students, and older adults, many of whom had varying levels of cognitive impairment. In addition I have taught and supervised numerous undergraduate research assistants.

3) Serve as a member of a geropsychology research group involved in a research project designed to evaluate the influence of memory capacity on medical and financial decision making abilities in elderly nursing home residents. This project entails conducting structured interviews and numerous standardized cognitive tests.

\section{Teaching Interests}

Introductory Psychology, Developmental Psychology, Life Span Development, Adult Development and Aging, Cognitive Development, Introductory Statistics, Introductory Research Methods, Gerontology 


\section{Teaching Experience}

Instructor:

Introduction to Gerontology, Fall 1996 - Present; approximately 120 students each semester, responsibilities include lecturing, grading, developing exams, and scheduling guest speakers to incorporate the multidisciplinary aspect of the course.

Introduction to Human Development, Spring 1995 - Summer 1996; approximately 120 students each semester, responsibilities included lecturing, grading, helping to develop exams, and individual direction for certain students.

Teaching Assistant:

Organismic Factors in Psychology, Fall 1992 - Fall 1993, 100 students per semester, 4 laboratory sections of 25 students each, gave instructions and guidance on computer generated labs and graded weekly papers and tests.

\section{$\underline{\text { Departmental Service }}$}

Member, Undergraduate Honors Thesis Committee, Department of Psychology, West Virginia University, Fall 1997 - Spring 1998

Graduate Student Representative, Curriculum Committee, Center on Aging, Education Unit, West Virginia University, Spring 1997

Student Representative, Microlab Committee, Department of Psychology, West Virginia University, 1995 - 1996

Graduate Student Representative, Developmental Training Committee, Department of Psychology, West Virginia University, Fall 1993 - Spring 1994

Member, Undergraduate Honors Thesis Committee, Department of Psychology, West Virginia University, 1992 - 1994

Graduate Student Representative, Full Faculty, Department of Psychology, West Virginia University, 1992 - 1993

\section{$\underline{\text { References }}$}

Dr. Stanley H. Cohen

Department of Psychology

P.O. Box 6040

West Virginia University

Morgantown, WV 26506-6040

Email: scohen@wvu.edu p p phone: (304) 293-2001, ext. 641 
Dr. David K. Brown

Center on Aging, Education Unit

P.O. Box 9127

West Virginia University

Morgantown, WV 26506-9127

Email: dkbrown@wvu.edu

phone: (304) 293-2081

Dr. Raymond J. Shaw

Department of Psychology

Merrimack College

315 Turnpike Street

North Andover, MA 08145

Email: rshaw@merrimack.edu

phone: (978) 837-5000, ext. 4374 